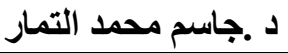

\title{
تقويم أداء معلمات الرياضيات من وجهة نظر طالبات المرحلة المتوسطة بدولة الكويت
}

لد . جاسم محمد التمار

استاذ المناهج وطرق التدريس المشارك

كلية التربية - جامعة الكويت

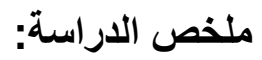

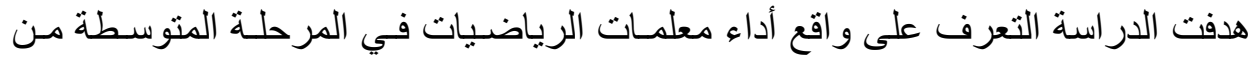

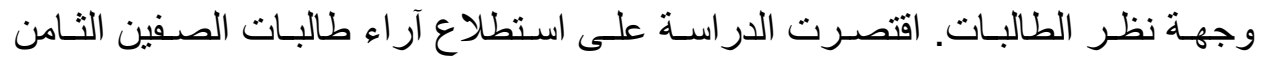

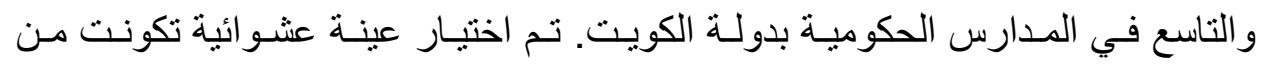

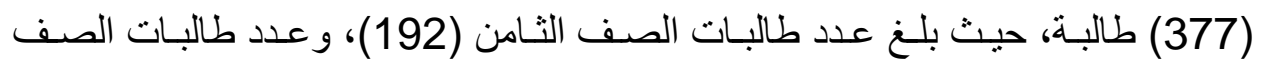

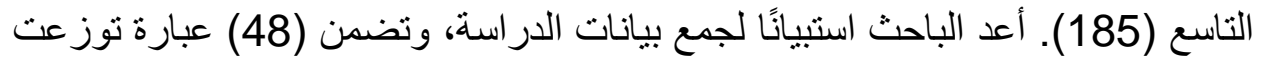

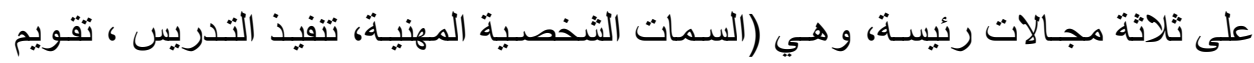

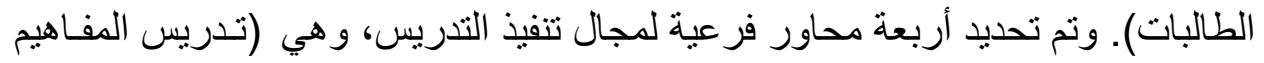

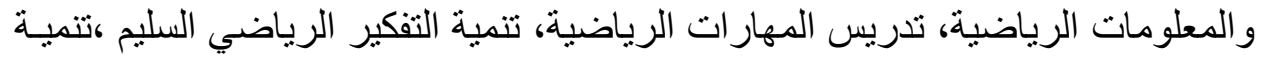

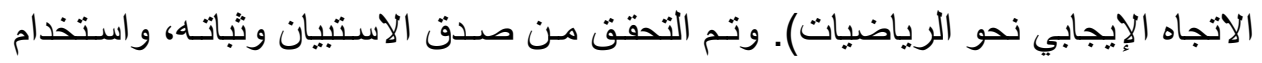

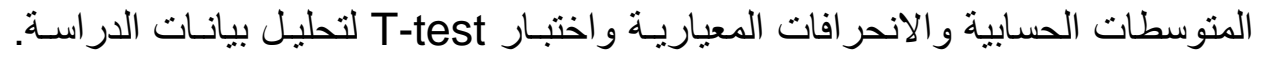
وجاءت أبرز نتائج الدراسة بالنقاط التالية:

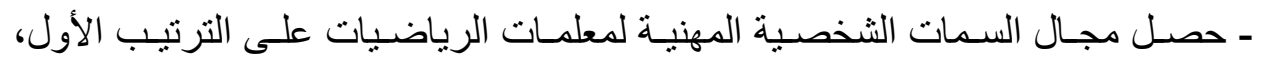
بمستوى أداء عالٍ، وأما تنفيذ التدريس فقد حصل على الترتيب الأخير، بمستوى أداء الترني متوسط.

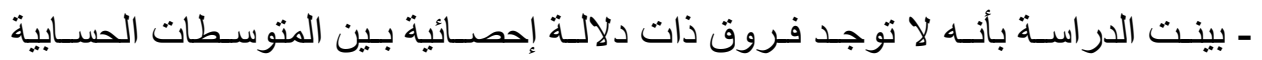

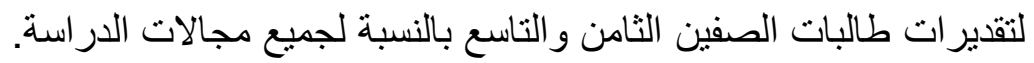

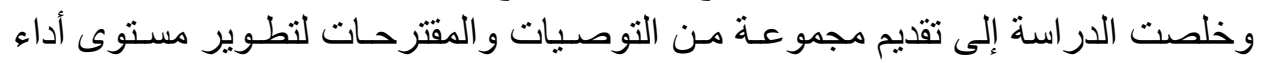
معلمات الرياضيات بدولة الكويت.

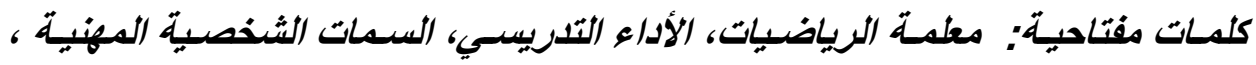
التقويم ، المرطلة المتوسطة. 
تقويم أداء معلمات الرياضيات من وجهة نظر طالبات المرحلة المتوسطة بدولة الكويت

AN EVALUATION OF FEMALE MATHEMATICS

TEACHERS' PERFORMANCES FROM THE PERSPECTIVES OF MIDDLE SCHOOL STUDENTS IN KUWAIT

Dr.Jasem Altammar

Associate Professor

Kuwait University, College of Education

\section{ABSTRACT}

This empirical research evaluates the performance of mathematics teachers, from the perspectives of middle school students in Kuwait. In line with the country's gender segregation across all public schools, the research samples female students and female teachers in the eighth and ninth grade levels. The randomized sample consists of 377 students, with 192 students in the eighth grade and 185 students in the ninth grade. Data collection methods involve a questionnaire of 48 items divided into 3 key domains - personal characteristics of mathematics teachers, implementation of mathematics teaching methods, and students' evaluations. Four additional sub-axes were identified for the implementation domain teaching mathematical concepts and information, mathematics teaching skills, mathematical critical thinking skills, and developing students' positive attitudes towards mathematics. After verifying the questionnaire's internal and external validity and reliability, data was collected and analyzed using arithmetic means, standard deviations, and T-tests.

Data analyzed revealed multiple findings. Results indicate the personal characteristics domain ranking first with a high level of teacher performance, while the implementation domain ranked last with a medium level of teacher performance. Additionally, the evaluation domain ranked second with a medium performance level. A majority of the items received a high performance level from the eighth and ninth grade students' perspectives, in the personal characteristics domain. The axis of teaching mathematical concepts and information obtained a medium and high level for teacher performance, while the remaining 3 axes attained a medium level for teacher performance in a majority of the items. Lastly, most of

العدد الخامس والاربعون (الجزء الثالث) ب r.r

(284)

مجلة كلية التربية- جامعة عين شمس 
the items related to the axis of students' evaluation also received a medium level for teachers' performance levels.

Research results reveal no statistical differences between the arithmetic averages of eighth and ninth grade students, in none of the 3 key domains. The research concludes with a list of practical recommendations for enhancing the performance of female mathematics teachers in Kuwait. Moreover, findings could prove useful for mathematics teaching settings beyond Kuwait and for country comparative mathematics literature.

Keywords: mathematics teachers; teacher performance; middle school; personal characteristics; evaluation . 


\section{تقويم أداء معلمات الرياضيات من وجهة نظر طالبات المرحلة المتوسطة بدولة الكويت}

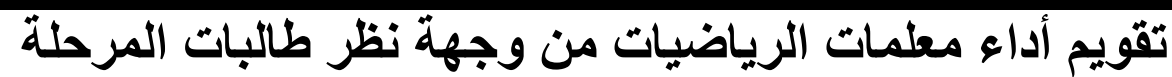 المتوسطة بدولة الكويث \\ د مداسم محمد التمار \\ استاذ المناهج وطرق التدريس المشارك \\ كلية التربية - جامعة الك}

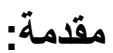

فرض العصـر الذي نعيثـهـ تحديات وتغيرات في جميع جو انب الحيـاة، بسبب التقدم التكنولوجي و الثورة المعرفية، مما أدى إلى تطوير المنظومـة التعليميـة والبـر امج التربويـة بأنو اعها لمو اكبة سرعة توسع وانتشار المعلومات في مجال التربية والتعليم، بهدف انتاج جيلاً قادرًا على التفاعل والتكيف مع متطلبات العصر، وتحقيق التقدم وتطلعـات مجتمعـه، مما ينطلب ذلك إلى تطوير دور المعلم وواجباتـه المهنيـة، ومسؤولياته ومهامـهـ للارتقـاء بالمتعلمين، لتتمية إمكاناتهم وقدر اتهم الذاتيـة. فـلا يمكن لأي مجتمـع أن بتقدم بـدون تقديم أفضل تعليم لأبناءه الطلبه. ولذلك يتطلع التعليم إلى وجود معلم متميز ذي شخصية متزنـه، ومتمكن من مادته العلمية، ويمتلك الكثير مـن الخبرات المتنوعـة والحديثـة في التدريس، ويتمتع بأفكار ومهار ات متجدده، ولدية الدافع و الرغبة الصادقة للتعامل و التفاعل مع الطلبـة

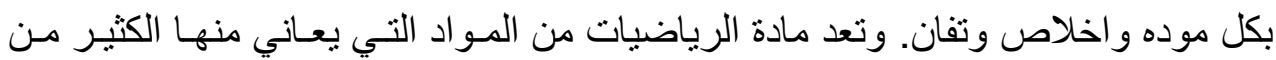
الطلاب بسبب صعوبة فهمها واستيعابها ، مما أدى إلى شـعور هم بـالقلق و الفشـل في مـادة الرياضيات ( Basar and Yalcin,2002) و أدى ذللك إلى العزوف عن در استـها. إن فثنل الطلاب في الرياضيات وتدني مستو اهم، و عدم حبهم لها، رغم أهميتها، بسبب ضـعف أداء معلمي الرياضيات عند تدريس مـادة الرياضـيات، ومحدوديـة خبر اتهم في استخدام المـداخل التدريسية الحديثنة، لإتـارة دافعيـة التعلم للدى الطلبـة، وقلـة الاهتمـام بالأنشطة الرياضية التي تؤدى إلى تحفيز مهار ات التفكير العليـا، وحلـل المشكلات الرياضية ، بـل يركز المعلمـين جـل اهتمـامهم على اسـتخدام الطـرق التقليديـة في تـدريس الرياضـيات، 


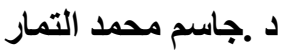

و التعامل بالتجريد، وتتجيع الطلبة على الحفظ و الاستذكار. علما بأن تعليم الرياضيات في هي

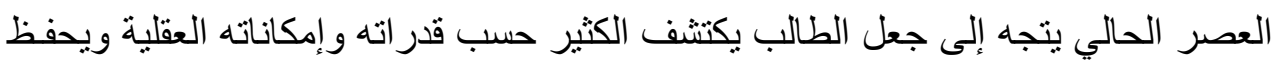
القليل. بعكس ما تعوّد عليه الطلبه خلال سنو اتهم الدراسية السابقة مـن سطحية المعلومـات وحفظها، وقلة المهار ات، والتركيز على مهار ات التفكير الدنيا، و إعدادِهم فقط لاجتيـاز الاختبار ات و الامتحانات. وفي ذلك يذكر عباس و العبسي (2009) أن الدراسات و البحـوث دلت على أن المتعلمين فثلوا في تفسير بعض الخطوات التي يقومـون بها بصـورة آليـة، بسبب تدريب المعلمين لهم على المعرفة الإجر ائية للوصول إلى الناتج دون فهم الخطوات التـي يقومـون بها ، و ععدم التركيز على المعرفـة المفاهيميـة، علمَا بـأن النظـرة الحديثـة لتدريس الرياضيات تقوم على المعرفة المفاهيمية، وفهم الأفكار الرياضية، والعلاقـات بين الأفكار وربطها ببعضها البعض بأسلوب ذب معنى. وهذا مـا تؤكده العديد مـن الدراسـات التربوية بأن شعور الطلاب وتخوفهم من الفتل في مادة الرياضيات بسبب تجاربهم السلبية مـع معلمي الرياضـيات (Basar \& Yalcin,2002). إن مـادة الرياضيات مـن أكثر

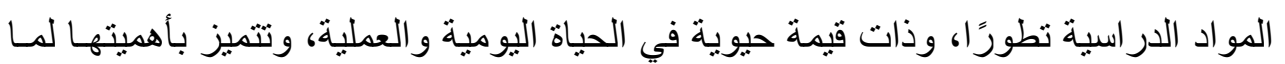

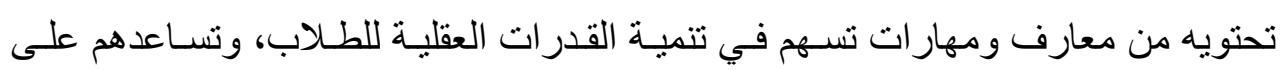
التفكير الرياضي السليم، وتنمي لديهم وسع الأفق في در اسة المشكلات الرياضية و الحياتيـة

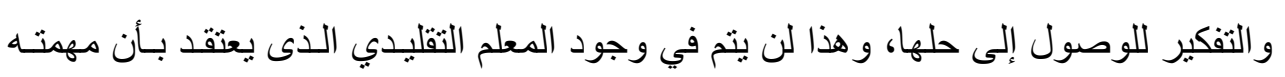

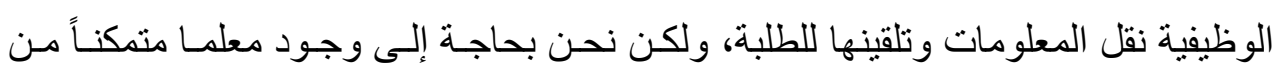
مادته العلمية، ملماً باستر اتيجيات وطر ائق تدريس الرياضيات الحديثة و المتنوعـة، ومؤمنـاً

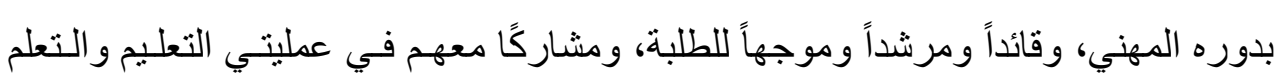

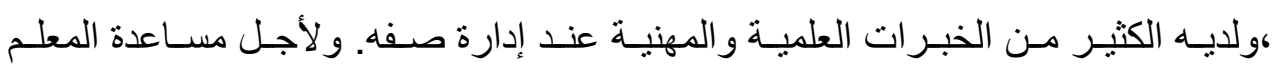
للنهوض بدورة العلمي والمهني، فقد حددت الوثيقة الصادرة عن المجلس القومي لمعلمي ولي ولهي الرياضيات بالو لايات المتحدة الأمريكيـة (NCTM,2000) الأدوار التي ينبغي أن يقوم

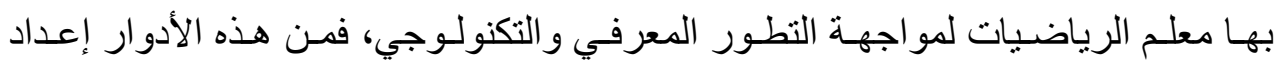


تقويم أداء معلمات الرياضيات من وجهة نظر طالبات المرحلة المتوسطة بدولة الكويت

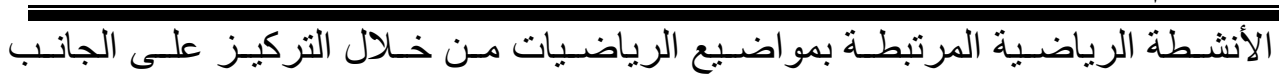
التطبيقي، وتجهيز بيئة التعليم والتعلم التي تستثير الطلبه وتحفز هم على تعلم حل المشكلات الرياضـية، و التـدريب على إقامـة الـرو ابط الرياضـية بـين العناصـر المختلفـة، و اسـتخدام التقنيات التعليمية لمساعدة الطلبة على تعلم الرياضيات. كمـا قـام المجلس القومي لمعلمي الرياضيات منذ عام (1991) بوضع معايير مهنية لمعلمي الرياضيات، وتضمنت المعايير

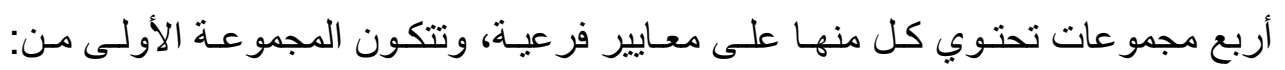
معايير تدريس الرياضيات، واشتملت على ستة معايير فرعية ومنها: المهام الواجب على تهى

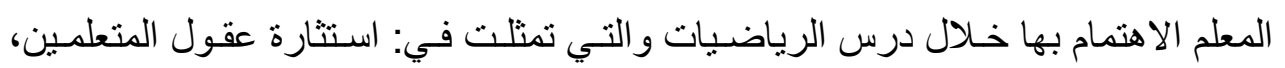
وتطـوير المهـار ات الرياضـية للمتعلمين، وزيـادة دافعيـة المتعلمـين لممارسـة الترابطـات الرياضية، والعمل على حل المشكلات الرياضية، وتشجيع التواصلـل الرياضـياتي، وتمثيل الرياضيات كنشاط انسـاني، ومر اعـاة الفروق الفرديـة، وتطوير اتجاهـات المتعلمين نحو الرياضيات، واستخدام الحاسوب والآلآت الحاسبة والتكنولوجيا التعليمية الحديثة، واستخدام

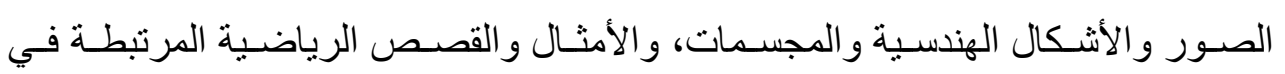

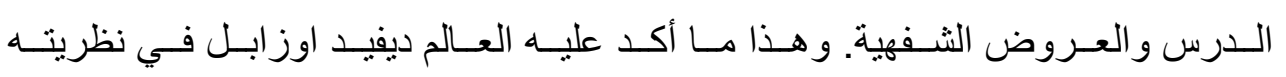
(Bell,1987)، حيث يرى أن يكون تعليم الرياضيات قائما على الفهم ذي المعنى، فيجب وهن

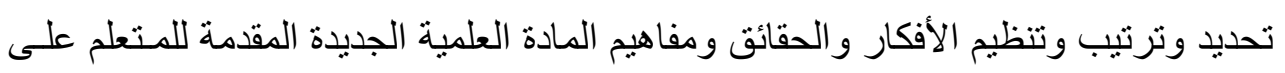

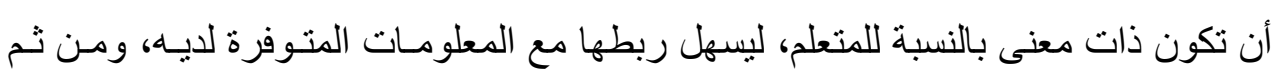

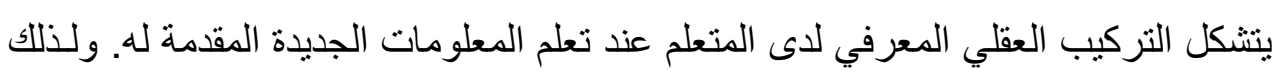
يجب على المعلم التسلسل التدريجي في تقديم المادة العلمية من الجزء إلى الكل، وأن يكون

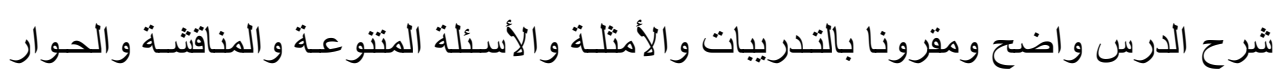

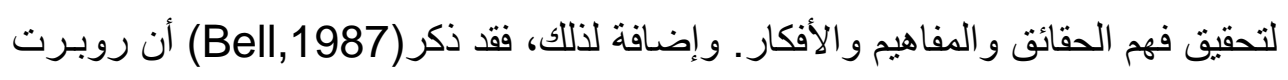

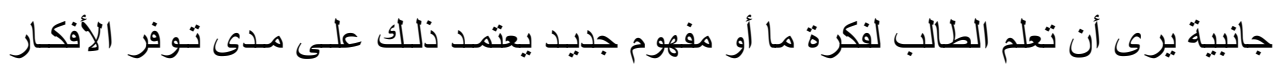

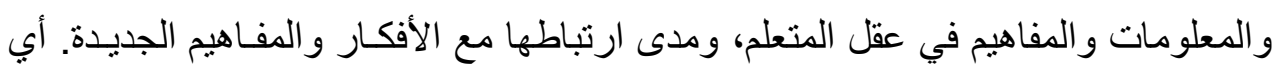




\section{داسم محمد التمار}

أن المعلومات تبنى في عقل المتعلم بتسلسل وتتابع منطقي، إذا تم تعليمها وتعلمها بتسلسـل داسل منطقي، وتـم ربـط المعلومـات الجديـدة بالقديمـة، مـع الاهتهـام بالبيئة الصـفية المحفزه و المشـجعة على عمليتي التعليم والتعلم، وتـوفر الأنشطة المصـاحبة لموضـوع الــرس، ووجود الوسائل التعليمية و التكنولوجية لمساعدة المتعلم على استيعاب المـادة العلميـة، في

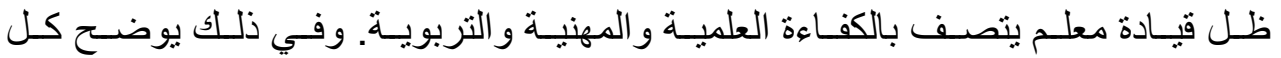

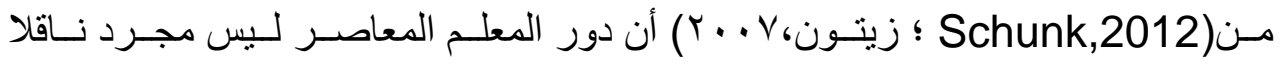
ومرسلا للمعلومات و المعـارف الموجودة في كتـاب الرياضيات، بـل أصبح دوره ميسر

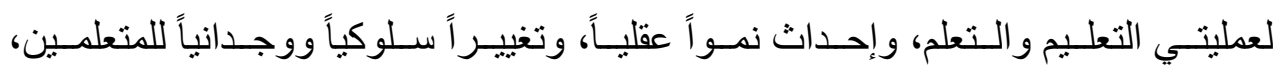
ومساعدتهم على اكتساب مهار ات التفكير، وحل المشكلات الرياضية، وأن يكون تعليم الرياضيات قائما على الفهم ذي المعنى، بالإضـافة إلى اسـتخدام مهـار ات التفكير و التأملـ و الإبداع. فالمعلم صانع للأجيال، ومنمي لعقولهم ،وموجـة ومرشـد لسـلوكياتهم، لذللك تقع عليه مسؤولية إعداد أجيال المستقبل، ورعايتهم وتوجيههم. وعلى الـرغم مـن أهميـة دور المعلم في تعليم الرياضيات لبناء جيل واعٍ ومدركٍٍ وقادر على التفاعل مع منطلبـات العصـر

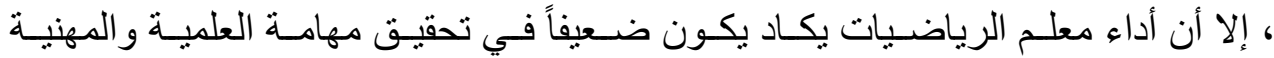

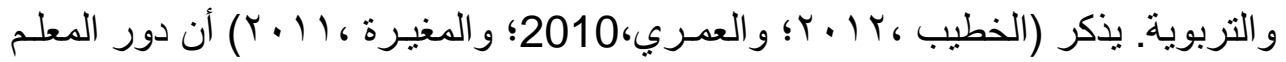
الضعيف يؤثر سلباً على مستويات طلابه في إكسابهم المهار ات الرياضـية، وتنميـة طرق تفكير هم، وتهيئة المنـاخ التعليمسي القـائم على الحـوار البنـاء، وحب الاسـنطلاع العلمي،

$$
\text { ومهار ات التفكير. }
$$

ولذلك تسعى وزارة التربية بدولة الكويت إلى تطوير أجيال تثوافق مـع منطلبـات العصـر الحديث، وتتميز بقدرات عاليـة في الأداء، ولتحقيق ذلك حرصت الوزارة على إيجـاد بر امج للإرتقاء بالمعلمين من خلال تمهين التعليم، و الاهتمـام بتتميـة المعلمين، وتطوير مهار اتهم وتجديد معلومـاتهم، وتطـوير طرق التـدريس، وتعزيـز المهار ات القياديـة في الصـفوف الدر اسـية، و التعامـل الإيجـابي والفاعل مـع المجتمع (وزارة التربيـة والتعليم 
تقويم أداء معلمات الرياضيات من وجهة نظر طالبات المرحلة المتوسطة بدولة الكويت

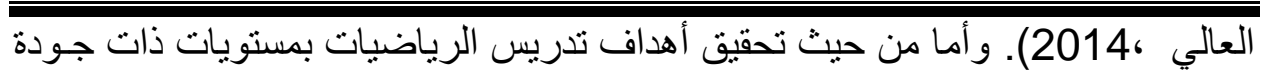

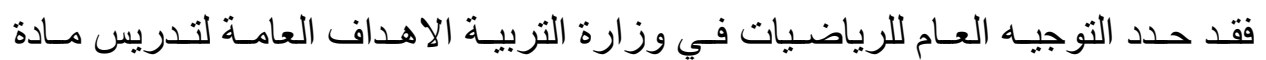
الرياضيات في المرحلة المتوسطة والتي تضمنت اربعـة أهداف وهي كالتـالي (التوجيـه الفني العام للرياضيات ،2018) : أهداف تتعلق بالمعرفة الرياضية:

- اكتساب المعرفة الرياضية اللازمة لفهم الجوانب الكمية في البيئة

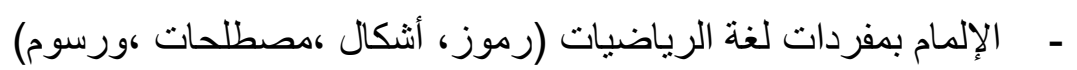
- - مهم المعاني وراء العمليات الرياضية - - تنمية الفهم لطبيعة الرياضيات كمنظومة متكاملة من المعرفة أهداف تتعلق بالمهار ات الرياضية: - اكتساب المهار ات الرياضية اللازمة لتفسير بعض الظواهر في الحياة اليومية - تنمية المهار ات الرياضية التي تساعد على تكوين الحس الرياضي - - تتمية القدرة على جمع وتصنيف البيانات الكمية وجدولتها وتمثيلها وقر اءتها - - اكتساب أساليب متنو عة لإجر اء العمليات الرياضية ولية - استخدام لغة الرياضيات في التو اصل و التعبير عن المو اقف الحياتية أهداف تتعلق بأساليب التفكير الرياضي السليم:

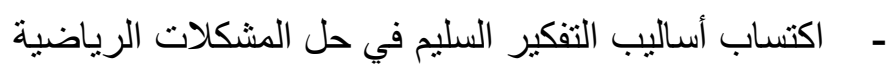
- - تطبيق خطو ات أسلوب حل المشكلات الرياضية - ت تمية القدرة على استخدام المفاهيم و المهار ات الرياضية في التعامل مـع مواقف

$$
\text { جديدة }
$$

أهداف تتعلق بالميول والاتجاهات و القيم:

- اكتساب قيم إيجابية مثل(الدقة، التنظيم ،المثابرة، الموضـوعية في الحكم علي

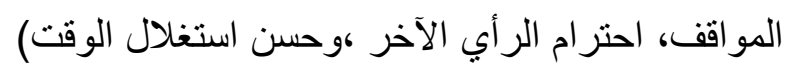




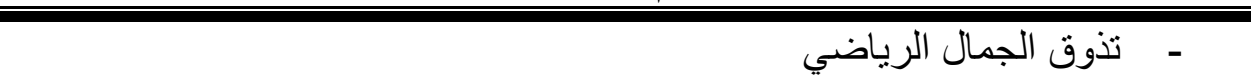

- متمية تقدير الذات للكفاءة الرياضية

- غرس حب الرياضيات لدى المتعلم وتعزيز اتجاهاته نحو تعلمها - الاستمتاع بالجانب الترفيهي في الرياضيات - - تقدير دور الرياضيات في حل مواقف حياتية

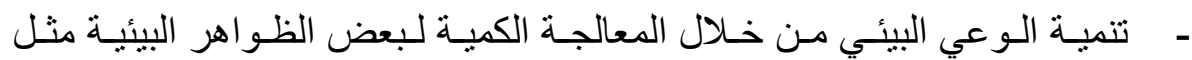

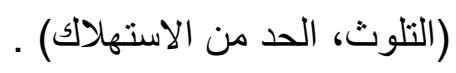

إن موضوع التعرف على مستوى أداء معلمي الرياضيات أخذ جانبًا هامًا مـن هـ

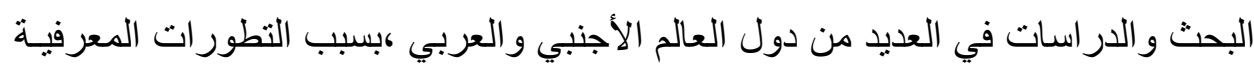
و العلمية والتكنولوجية المتسار عة التي تجوب دول العالم المختلفة ، لذا فقد سـلطت العديد من الأبحاث و الأدبيات تقييم مستوى أداء معلمي الرياضيات ، ففي الدر اسـة التي اجر اهـا (Hardi,et all,2021) تحفيز الطلاب للتحصيل العلمي لمادة الرياضيات. ولتحقيق هدف الدراسة، تـم أخذ عينـة إلــ عشو ائية بلغت(277) طالب من الصف الثامن من المدارس الإعدادية مـن سـت مدارس حكومية ومدرستين خاصتين في أندونيسيا، وتم تطبيق استبانة عليهم. أظهرت نتـائج الدراسة أن أداء معلم الرياضيات وقدرتة على تحفيز الطلبة على تحصيل الرياضيات أثر بشكل كبير على اهتمام الطلبة وعلى التحصيل العلمي في الرياضيات، حيث يعد أداء

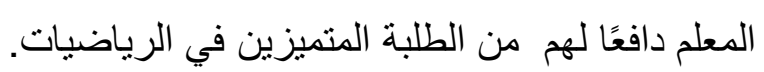
كما أجرى (Akbas,Murat and Esra,2019) در اسة في تركيا هدفت إلى في لهي

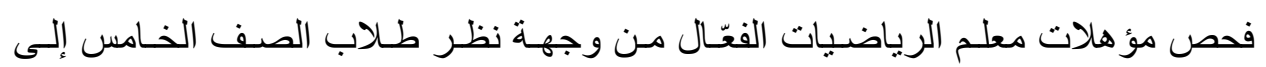

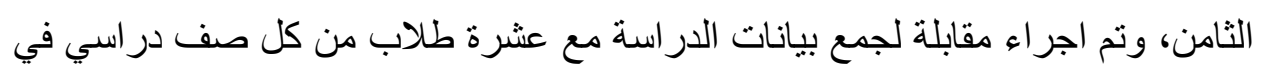

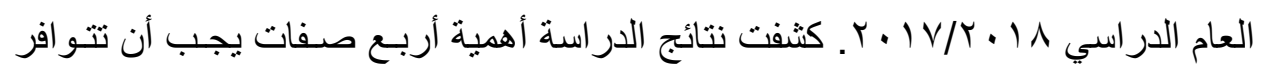

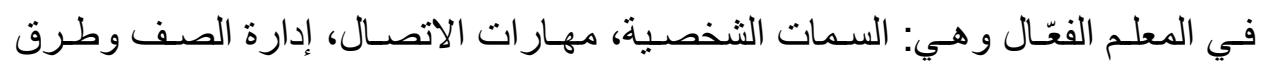




\section{تقويم أداء معلمات الرياضيات من وجهة نظر طالبات المرحلة المتوسطة بدولة الكويت}

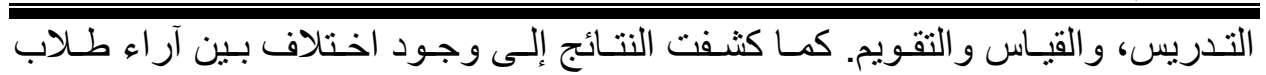
الصفوف الأربعة فيما يتعلق بمستويات تفكير هم وحاجاتهم.

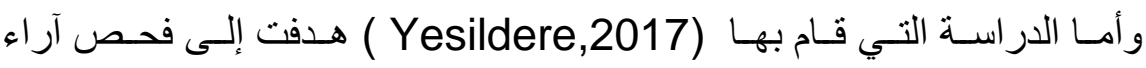
مديري المدارس و المعلمين وطلاب المدارس المتوسطة في تركيا، حول الصـفات التي

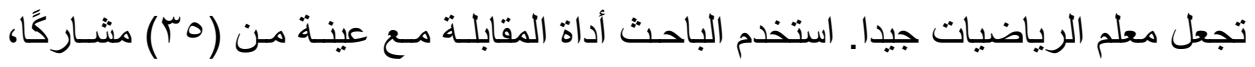
وتتمثـل العينـة في التـالي: مـدر اء مـدارس (· ())، مدرسـين رياضـيات (· ( )، طـلاب المرحلة المتوسطة (0 (1). توصلت نتائج الدراسة إلى اتفاق الطـلاب و المدر اء و المعلمين على أن معلم الرياضيات الجيد يجب أن يعرف “كيف يُعلم الرياضيات ؟ “، وأن يشـرح

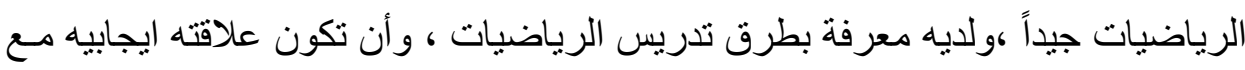
الطلبه، و أن لا يغضب بسر عة، وأن يساعد الطلبة على فهم مو اضيع الرياضيات، وينمسي

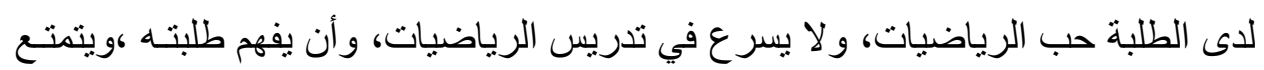

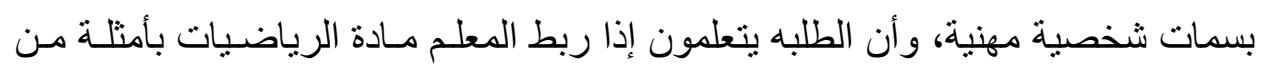
و اقع الحياة اليومية موضحا ذللك بالصور و الرسومات المختلفة.

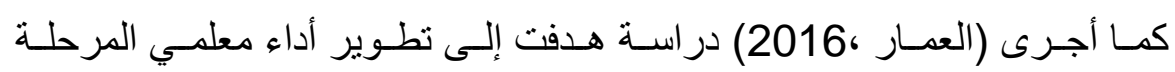
المتوسطة بدولة الكويت في ضوء الاتجاهات الحديثة. واستخدم الباحث المنهج الوصفي

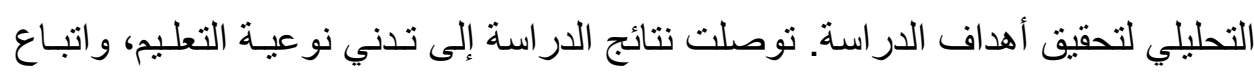

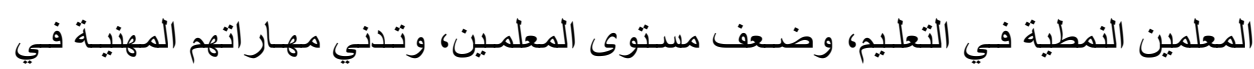
المرحلة المتوسطة.

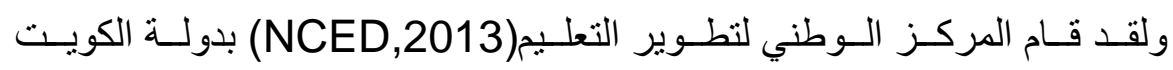
بالمشاركة مع المعهز الوطني للتعليم بجامعـة نانيـانغ التكنولوجيـة في سـنغافورة بـاجر اء

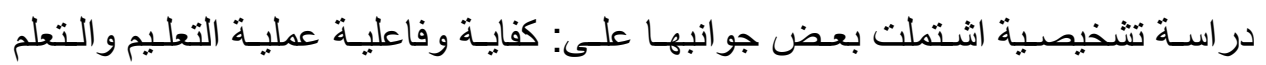
(المناهج وطرق التدريس و التقييم)، و التكنولوجيا، وتـدريب المعلمين. وخلصـت الدراسـة إلى مجموعة من الحاجات ومنها: الحاجة إلى اختبار ات تقويميـة لتحفيز المهار ات العليـا 
لـ إسم محمد التمار

للتفكير ؛ والحاجة إلى تحسين الكفـاءة المهنيـة للمعلمين ؛ والحاجـة إلى وضـع أداة تقيجم فعّالة لأداء المعلمين ( وزارة التربية و التعليم العالي ، 2014) .

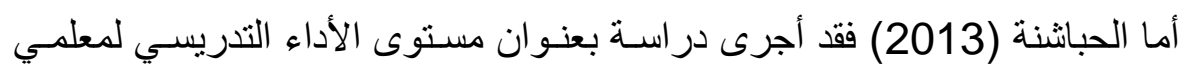
الرياضيات للصف العاثر الأساسي بمحافظـة الكرك، مـن وجهة نظر الطلبـه. استخدم الباحث المنهج الوصفي لمناسبته في تحقيق أهداف الدراسـة، واستخدم أداة الاستبانة لجمع بيانات الدراسة، و التي تكونت من (48) فقرة، موزعـة على سـتة مجـالات هي:

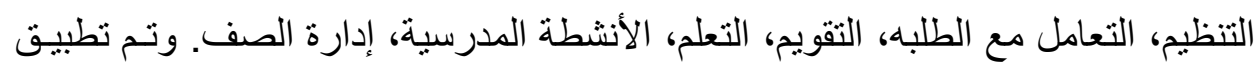
الدراسة على عينه عشو ائية تكونت من (169) طالبا وطالبة. أظهرت نتائج الدراسـة أن مستوى الأداء التدريسي لمعلمي الرياضيات مرتفع في جميع المجالات، ما عدا الأداء في مجال الأنشطة المدرسية فكان بدرجة متوسطة. وقد أجـرى (Taylor \& Taylor,2012) در اســة هدفت إلى معرفـة أتثر تقيبم المعلمين للمساهمة في تحسين آدائهم. أظهرت نتائج الدراسـة أن المعلمين يكونـون أكثر إنتاجية في السنوات التي تلي تقويم أدائهم، كمـا أشـارت النتائج إلى أن المعلمين بمكنهم

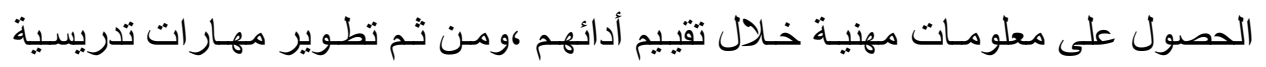
ومهنية جديدة لديهم.

وفي دراسة (الدهش ،2009) التـي أجر اهـا على عينـة عشـوائية تكونـت مـن 60

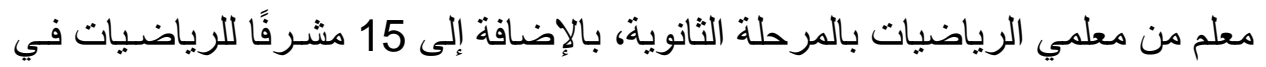
السـعودية، بهدف تقويم أداء معلمسي الرياضـيات في مدارس مدينـة الريـاض. استخدم

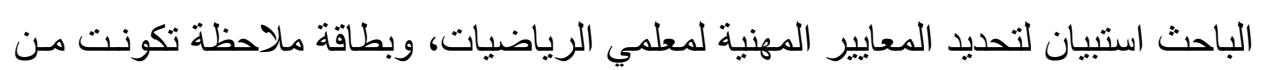
(T (1) معيارًا. وتوصلت نتائج الدراسة إلى التالي: أن درجة كل من معيار التنمية المهنيـة وتحسـين الأداء لمعلمـي الرياضـيات، ومعرفـة المعلمـين بطبيعـة الرياضـيات، وقـدرة

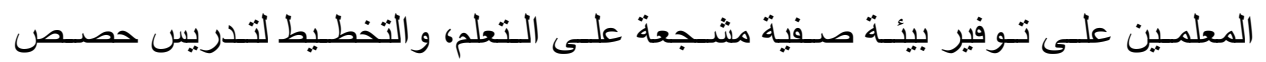

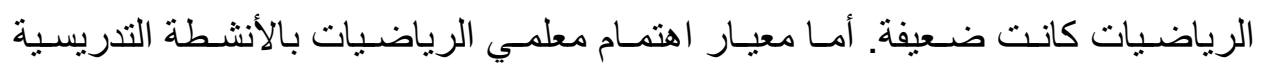




\section{تقويم أداء معلمات الرياضيات من وجهة نظر طالبات المرحلة المتوسطة بدولة الكويت}

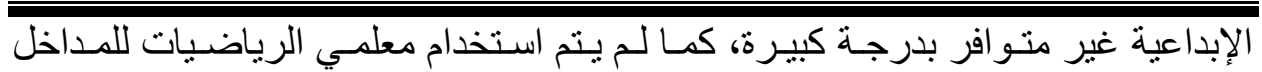
التدريسية الحديثة إلا بشكل محدود، بالإضافة إلى أن عملية تقويم المعلمين لطلابهم لم يتم في ضوء المعايير المهنية. أما ( الفر هود ، 2008) فقد أجرى دراسة هدفت إلى الوقوف على واقع الأداء في تـدريس الرياضـيات في المرحلـة الثانويـة بمدينـة عرعـر بالسـعودية، مـن وجهـة نظـر

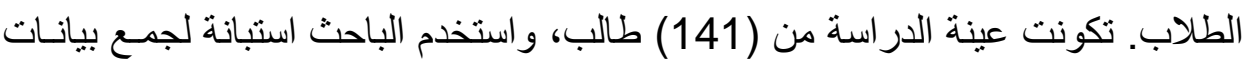
الدر اسة. أظهرت نتائج الدر اسة أن درجة الأداء في تدريس الرياضيات كانـت ضـعيفة، ووجود فروق في الأداء التدريسي بين المعلمين بـاختلاف صف التدريس، والخبرة، ونصاب الحصص لكل معلم.

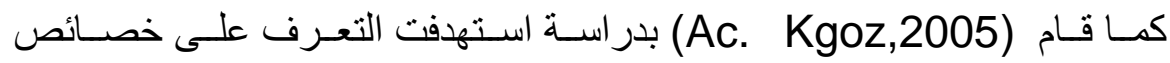
المعلمين وتأثير اتهم على اتجاهات الطلبة في مدارس تركيا. استخدم الباحث استبانة لجمع

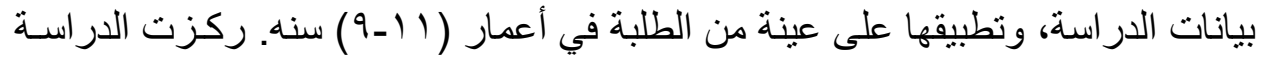
على معرفـة تصـور ات و إدر اكـات الطلبــة لخصــائص معلمـيهم المهنيـة، و التربويـة، و الثخصية. أظهرت نتائج الدراسة إلى وجود فروق ذات دلالـة احصـائية تعـزى لمتغير الجنس ، حيث أن الطالبـات أكثر حساسية لثخصية معلميهم مـن الطـلاب، بينمـا اهنم الطلاب بمعارف معلميهم، وسعة اطلاعهم، وأخلاقهم، وطبـائعهم. كمـا أبرزت النتائج صفات المعلم غير المقبولة لدى الطلبـة وهي: التمييز في التعاملـ، واستخدام الأسـاليب المملة، والقسوة، و عدم الاهتمام بالملبس و الهندام و الثـكل، والصـر اخ، وفقدان السبطرة على الصف.

وأجـرى (Joseph,2004) در اسـة هـدفت التعـرف إلى مـدى معرفـة معلمي

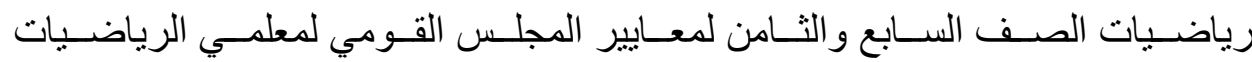
(NCTM,1991,2000)، ومدى توظيف هذه المعايير في تدريسـهم للرياضيات وفقـا لخبر اتهم التدريسية. تكون مجتمع الدر اسة من معلمي رياضيات الصفين السـابع والثامن، 


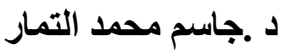

في جنوب شرق الو لايات المتحدة الأمريكية، وبلغت عينـة الدراسـة (41) معلم ومعلمهـ. توصلت نتائج الدراسة إلى أن المعلمين بشكل عام لا يحققون مستوى عـالٍ مـن المعرفـة حول استخدام المعايير الصادرة من NCTM، كما أن العديد منهم غير ملمين بالمعايير.

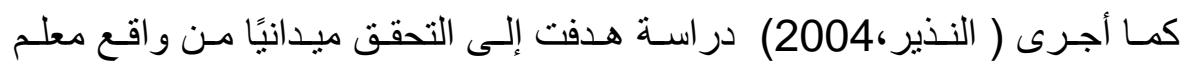
الرياضيات في المرحلة المتوسطة في المملكة العربية السعودية. استخدم الباحث المنهج الوصفي لتحقيق أهداف الدراسة، وقـام ببنـاء وتطبيتق أداة الملاحظـة لتقويم مستوى أداء

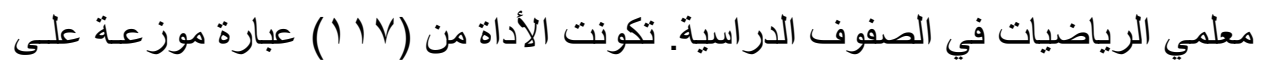
ثمانية مجالات وهي: تخطيط تـدريس الرياضيات، تنفيذ اسـتر اتيجيات التـدريس، تقديم المعرفـة الرياضـية، بنـاء وتطـوير المفهـوم الرياضـي، تنميـة التفكيـر، تتميـة العلاقـات و الاتصال اللفظي، استخدام وسائل وتقنيات تعليم الرياضيات، التقويم و الأسئلة الصفية.

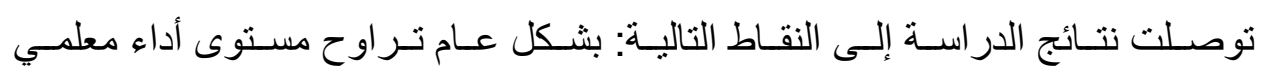

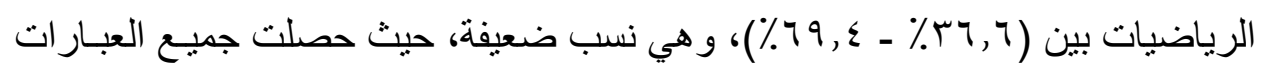

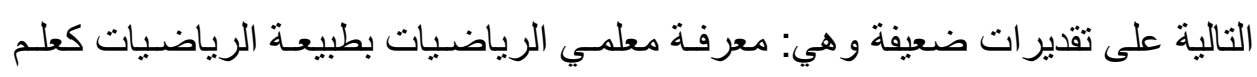

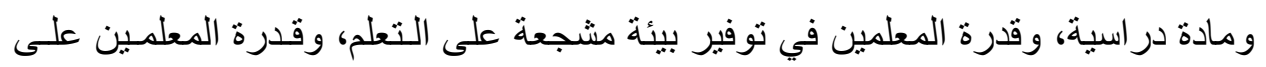
إدارة زمـن حصــة الرياضـيات، وتخطيط دروس الرياضـيات بطـرق حديثـة، و اهتمسام المعلمين بالأنشطة التدريسية الإبداعية. يلاحظ من استعر اض الدر اسات السابقة أن نتائج العديد من الدراسات دلت على وجـود

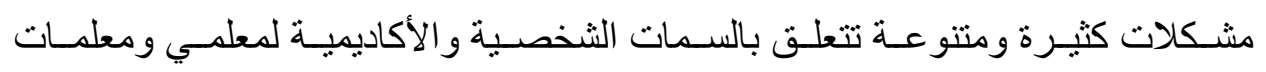

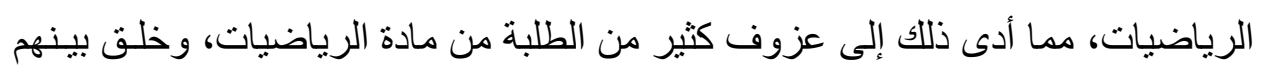

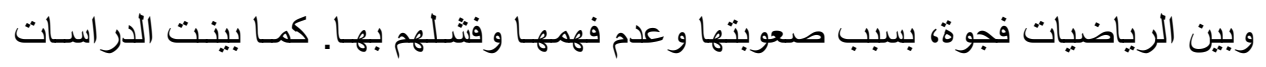

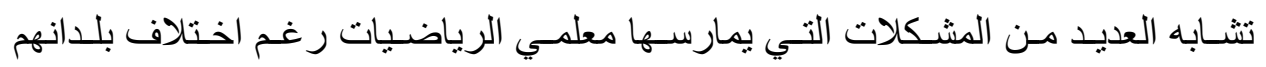
وبر امج إعدادهم ونوعية طلابهم. ولذلك أوصت الدراسات بضرورة تطوير أداء معلمي الرياضيات، و إكسابهم المهار ات اللازمة لأداء أعمـالهم بنجـاح. واختلفت الدر اسـات عن ونـ 


\section{تقويم أداء معلمات الرياضيات من وجهة نظر طالبات المرحلة المتوسطة بدولة الكويت}

بعضها البعض في الأدوات المستخدمة لجمع البيانات فمنها استخدمت الملاحظة، وأخرى

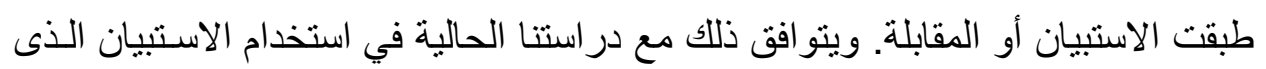
يعد من أحد أساليب تقويم أداء المعلم، ومن أكثر الأدوات شيوعًا، ويغطي عددًا كثيرًا مـن

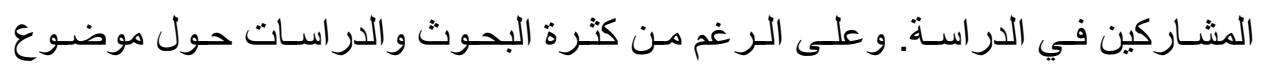

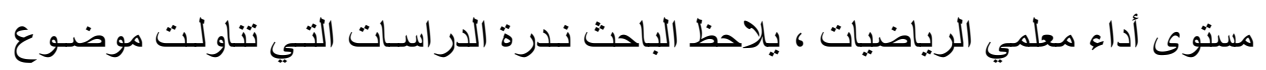

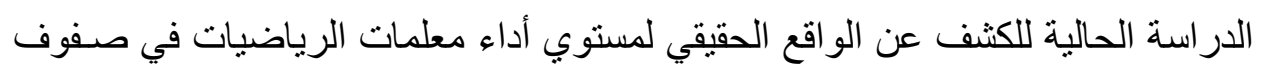
المرحلة المتوسطة، ومعرفة رأي طالبات هذه المرحلة في أداء معلماتهن. ولقد تم استفادة

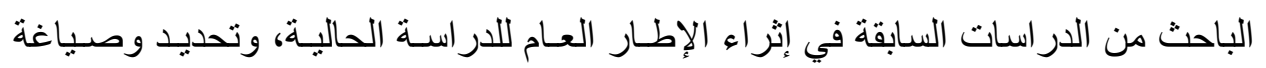

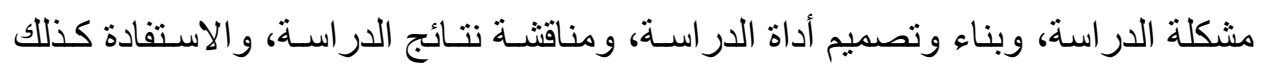

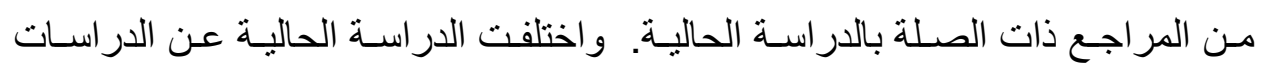

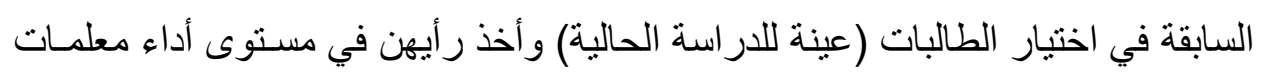
الرياضيات في صفوفهن الدراسية. بالإضافة إلي البحث بعمق في الجوانب البـ المعرفيـة ،

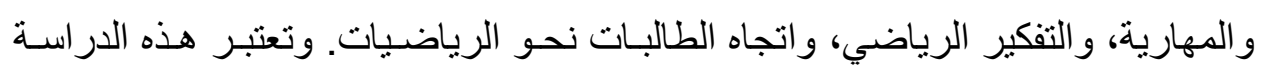
إضافة للار اسات السابقة.

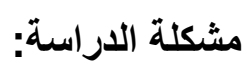
إن عملية تطوير مستوى أداء معلمة الرياضيات مهنيًا و علميًا بحاجـة إلى معرفـة واقع مستوى أدائها الفعلي في حجرة الدراسة، من خلال استخدام أدوات ونماذج متتو عة لتقويم سماتها الثخصية وأدائها التدريسي و علاقتها وتفاعلها مع طالباتها، بهدف تحسين أدائها

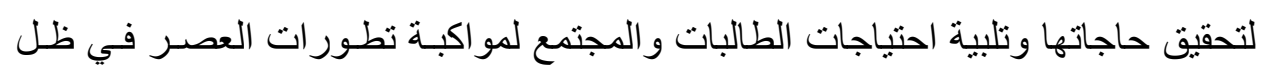
الثورة العلمية و المعرفية و التكنولوجية. وتعتبر آراء طالبات المرحلة المتوسطة في تحديد

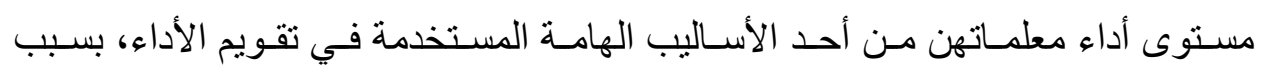

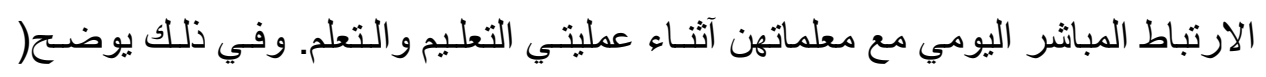
يوسف ،72:2007) أن تقويم أداء المعلم من وجهة نظر طلبته من الطر ائق الهامـة في 


\section{داسم محمد التمار}

عمليـة التقويم، باعتبـار هم الجانب المهم في العمليـة التعليميـة التعلميـة. وتعـد المرحلـة المتوسطة من المر احل الدراسية الهامة لموقعها بين المرحلتين الابتدائية والثانوية، ولدى طالبات كل مرحلة الكثير من الحاجات و الخصائص التي تتطلب رعايـة و عنايـة خاصـة، و لا بمكن أن تحققها أي معلمة رياضيات إلا عندما تتوفر لديها سمات شخصية مهنية معينة، وتمتلك قدرات علمية وسلوكية عالية. ولهذا ومـن خـلال واقع الأدبيـات النظريـة ونتـائج الدر اسـات السـابقة، و الدراسـات التـي أجريـــ لتقـويم مسـتوى الأداء التدريسـي

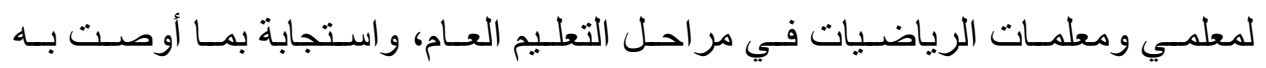
المؤتمرات والمنظمات العالمية مثل المؤتمر الدولي المنعقد في سلطنة عمـان (2004)، و المؤتمر المنعقد في دولة الإمارات العربية (2007)، والمؤتمر الخـامس المنعقد بكليـة التربية بجامعة أم القرى بالمملكة العربية السعودية (1437هجري)، والمجلس القومي

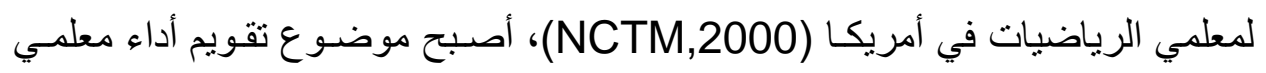
الرياضيات بحاجة إلي مزيد مـن الدراســات العلميـة والتربويـة. ولذللك أصبح تقويم أداء معلمة الرياضيات بصورة دورية ومستمرة ضرورة ملحة لرفع مستوى كفاءتها وتطوير

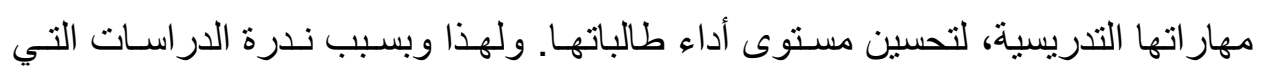

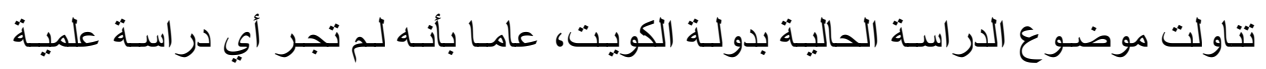

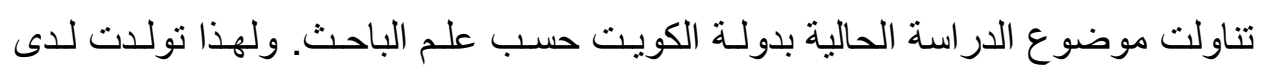

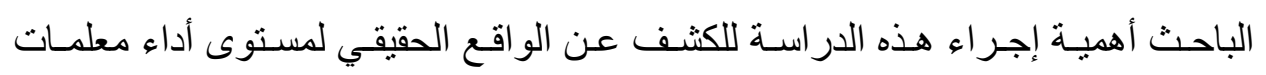

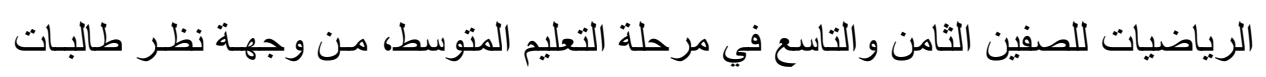
الصفين. وتحددت مشكلة الدر اسة بالإجابة على الأسئلة التالية:

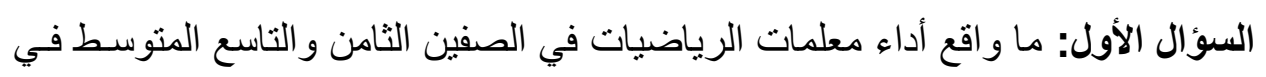
مجالات (السمات الثخصية المهنية، وتتفيذ التدريس، وتقويم الطالبـات) بدولـة الكويت، من وجهة نظر طالبات الصفين الثامن والتاسع ؟ ماته 


\section{تقويم أداء معلمات الرياضيات من وجهة نظر طالبات المرحلة المتوسطة بدولة الكويت}

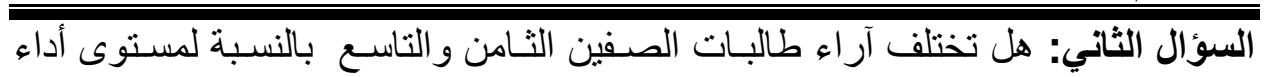
معلمات الرياضيات في مجالات (السـمات الثخصية المهنيـة، وتنفيذ التدريس، وتقويم الطالبات)، تبعاً لمتغير الصف الدراسي؟ أهداف الاراسة تهدف الدر اسة الحالية إلي الآتي: - التعرف على السمات الثخصية المهنيـة التي تتصف بهـا معلمـات الرياضيات في المرحلـة المتوسطة عند مزاولـة مهنـة التدريس، مـن وجهة نظـر طالبـات الصفين الثامن و التاسع المتوسط. - - التعـرف على مسـتوى الأداء التدريسـي لمعلمـات الرياضـيات للصـفين الثـامن

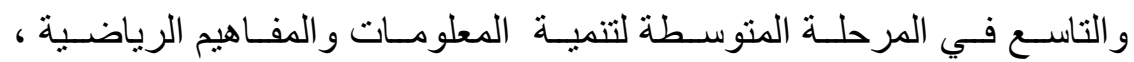
و المهار ات الرياضية، وأساليب التفكير الرياضي، والاتجاه نحو الرياضيات لدى طالبات المرحلة المتوسطة.

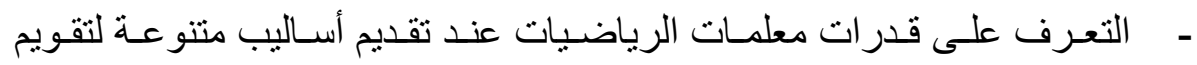
التحصيل الدر اسي لطالبات الصفين الثامن والتاسع في المرحلة المتوسطة.

\section{أهمية الار اسة}

تسنمد الدر اسة أهميتها بالنقاط التالية: - - توفير أداة للقائمين على تقويم الأداء الأكـاديمي والمهني لمعلمـات الرياضـيات، يمكن استخدامها عند تقويم معلمات المرحلة المتوسطة بدولة الكويت.

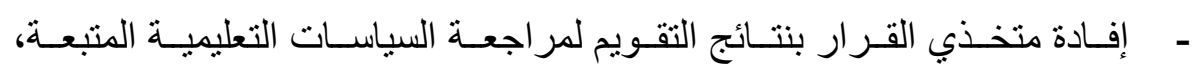
و التخطيط لتنمية المعلمات أكاديميًا ومهنيًا. - إفادة معلمـات الرياضـيات مـن أداة التقويم، لتقويم أنفسـهن وتحديــ احتياجـاتهن لتطوير مستوى آدائهن عند تدريس الرياضيات. 


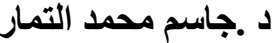

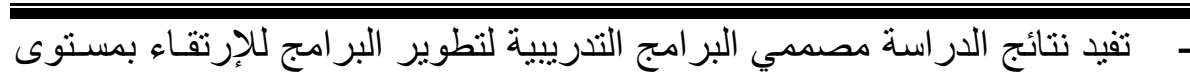
الأداء التدريسي و المهني لمعلمات الرياضيات. - الارتقاء بجودة تدريس الرياضيات من خـلال تحديد نقاط الضـعف و القوة للدى معلمات الرياضيات ، و العمل على علاج نقاط الضعف ،وتعزيز نقاط القوة. - في كليـات التربيـة بدر اسـة جو انب القصـور لـدى معلمـات الرياضـيات أثنـاء

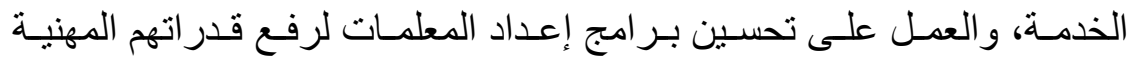
و الأكاديمية لتدريس الرياضيات.

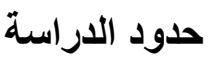
اقتصرت الدراسة على الحدود التالية: ـاستطلاع ر أي طالبات الصفين الثامن و التاسـع في المرحلـة المتوسطة في المـدارس الحكومية بدولة الكويت حول السـمات الثخصـية المهنيـة لمعلمـات الرياضـيات، وتنفيذ تدريس الرياضيات، و أساليب التقويم التي تتبعهـا معلمـات الرياضـيات لتقويم التحصيل

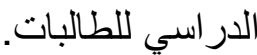

-تم تطبيق الدراسة في الفصل الدراسي الأول للعام الجامعي 2020/2019. مصطلحات الدراسة تقويم أداء المعلم :عرفـه (اللقاني والجمـل ،2003:21:203 كل مـا يصـدر مـن الفرد مـن سلوك لفظي أو مهاري، وهي يستند إلى خلفية معرفية وجدانية معينة ،و هذا الأداء يكون مهن عادة على مستوى معين بظهر فيه قدرته أو عدم قدرته على أداء عمل ما .

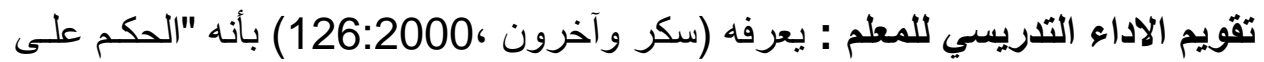
مسـتوي امـتلاك المعلم للمعـارف و المهـار ات و الإتجاهـات الضـرورية لأداء مهامسه في تهي

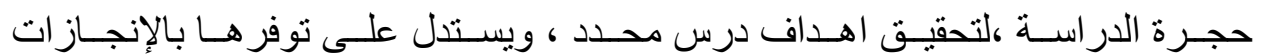
(الأداءات) (الث) 
ويقصد الباحث بتقويم أداء معلمة الرياضيات إجر ائيًا في هذه الدر اسـة هي الممارسـات التعليمية والاساليب التربوية التي تتبعها معلمات الرياضيات أثناء تنفيذ التدريس وتقويم

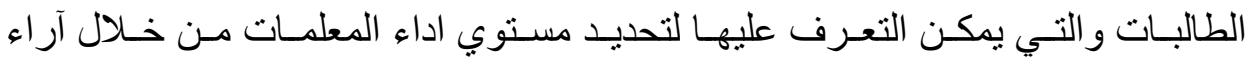
الطالبـات ـ وقـد حـد الباحث 3 مجـالات لتحديـد المسـنوي وهـي : مجـال السـمات الثخصية المهنية ؛ ومجال تتفيذ التدريس الذي يشتمل على أربعة محاور وهي: تدريس

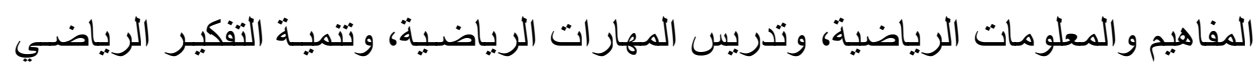
السليم، وتنمية الاتجاه الإيجـابي نحـو الرياضـيات. و ومجـال تقويم الطالبـات في الصفين الثامن والتاسع في المرحلة المتوسطة.

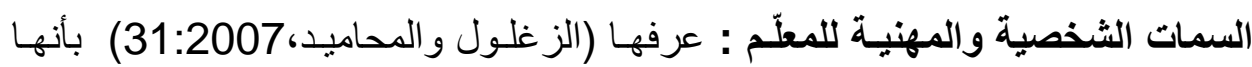
مجمو عة من السـمات الاجتماعيـة و الانفعاليـة و المهنيـة التي تجعل مـن شخصية المعلم متزنة ومؤثرة في المتعلمين، بحيث تلعب دور ا بارزا في إدارة جهودهم و توجيهها نحو تحقيق اهداف التعلم ،ومن هذه السمات:الاتزان العاطفي ،تأكيد الذات ،التفاعل الاجتماعي ،الأعداد المهني ،سعة الاطلاع ،المرونة ،معرفة المتعلمين. معلمات الرياضيات في المرحلة المتوسطة : المعلمـات الذين يقومسون في تدريس مـادة الرياضيات في مدارس المرحلـة المتوسطة مـن الصـف السـادس إلى التاسـع في وزارة

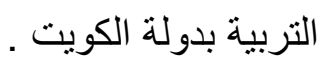

\section{منهج الدراسة}

اعتمد الباحث على المنهج الوصفي التحليلي للتعبير عن المشكلة المدروسة نوعياً وكمياً،

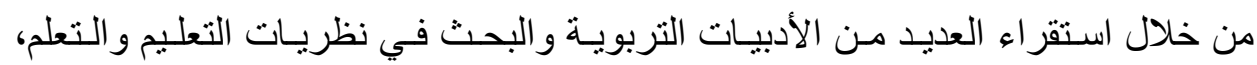
و الدراسات المتعلقة بتقويم أداء معلمي ومعلمـات الرياضيات في بعض الدول العربيـة والأجنبية. 
تكونت عينة الدر اسة من مجمو عة طالبات المرحلة المتوسطة للصفين الثامن والتاسع في المدارس الحكومية بدولة الكويت، المسجلين في العام الدراسي 2020/2019. بلـغ عدد العينة الإجمالية (ن= 377) طالبة، تم اختيار ها بطريقة عشو ائية، حيث بلغ عدد طالبـات

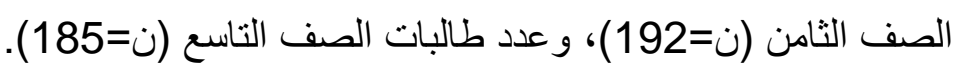
أداة الدراسة

تم تصميم الاستبيان مـن خـلال الاطـلاع و الاسـتفادة مـن الادبيـات النظريـة والدراسـات

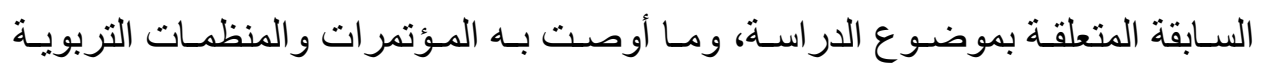
العالمية عند تقويم أداء معلمي الرياضـيات ،وخبـرة الباحث في مجـال المنـاهج وطـرق

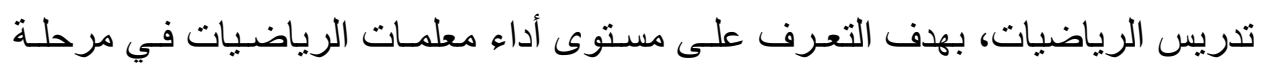

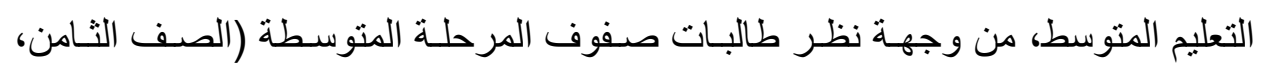
والصف التاسع).تكوّن الاستبيان في صورته الأوليـة مـن (54) عبـارة، تم تقسيمها إلى لى

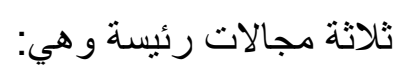

مجال السمات الشخصية المهنية: اشتمل على (8) عبار ات

مجال تتفيذ التدريس : اشتمل على (39) عبارة

$$
\text { مجال تقويم الطالبات : اشتمل على (7) عبارة }
$$

معيار الحكم: استخدم الباحث مقياس رباعي متدرج، وتم استخدام المدى في توزيع

(1) الارجات وفق جدول

\begin{tabular}{|c|c|c|c|}
\hline أو افق بدرجة متدنية & أو افق بدرجة & أو افق بدرجة & أو افق بدرجة عالية \\
\hline $1-1,100$ & $1, V 0-r, 0$ & $r, O-r, r_{0}$ & $r, Y o-\varepsilon$ \\
\hline
\end{tabular}




\section{تقويم أداء معلمات الرياضيات من وجهة نظر طالبات المرحلة المتوسطة بدولة الكويت}

صدق الاستبانة

للتحقق من صدق محتوى الاستبانة، نم عرضها في صورتها الأوليـة على مجموعـة مـن

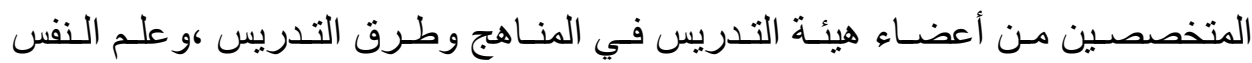
التربوي في كلية التربية بجامعة الكويت، وكلية التربية الأساسية في الهيئة العامـة للتعليم التطبيقي، وبلغ عدد المحكمين (9). طلب منهم إبداء آرا ئهم من حيث شـمول العبارات،

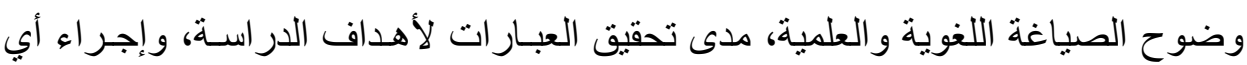
تعديلات أو إضافات أو إلغاء بعض عبار ات الاستبانة، حتى تتسم الاستبانة بالموضـوعية. وفي ضـو آر اء المحكمين تـم إجـر اء التعديلات اللازمـة، واعتبر هذا الإجـر اء بمثابـة الصدق الظاهري للاستبانة. و اشتملت الصورة النهائية للاستبانة على (48) عبارة، حيث اشتمل مجال السمات الشخصية المهنية على(7) عبار ات، واشتنمل مجـال تنفيذ التدريس على(37) عبارة، واشتمل مجال تقويم الطالبات على(4) عبار ات.

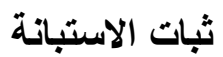

تم التحقق من ثبات الاستبانة باستخدام تطبيقها بو اقع مرتين على عينـة اسـنطلاعية بلغت (20) طالبـه مـن صـفوف الثـامن والتاسـع، وتم إعطـاء مـدة أسبو عين بـين التطبيقين للاستبانة ـ ثم تم حساب معامل سبيرمان بر اون و الذي بلغ \%82.3\%، ويعتبر هذا المعامل جيداً لتطبيق الاستبانة على العينه الفعلية للدر اسة.

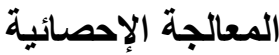

تم استخدام برنامج الـرزم الإحصـائية للعلوم الاجتماعيـة (SPSS) في تحليل البيانـات وذلك باسـتخدام المعالجـات الإحصـائية الوصـفية، وتـم اسـتخدام المنوســات الحسـابية و الانحر افات المعيارية للإجابة على أسئلة الدر اسة، واستخدام اختبـار (ت) لحسـاب دلالـة

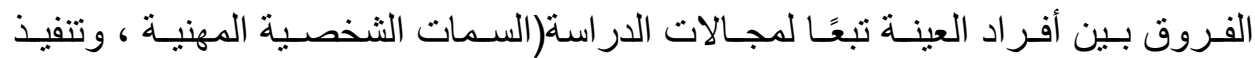
التدريس، وتقويم الطالبات) للصفين الثامن و التاسع المتوسط. 


\section{نتائج الاراسة ومناقشتها}

أولاً: النتائج المتعلقة بالسؤال الأول و الذي ينص على: " ما واقع أداء معلمـات الرياضيات في الصفين الثامن و التاسـع في مجـالات (السـمات الثخصية المهنيـة، وتنفيذ التـدريس، و تقويم الطالبات) بدولة الكويت، من وجهة نظر طالبات الصفين الثامن والتاسع ؟" تم حساب المتوسطات الحسابية و الانحر افات المعيارية وتقدير درجـة مستوى الأداء لكل مجال من المجالات الثثلاثة. جدول (2) يوضح ذللك.

جدول (2) المتوسطات الحسابية والانحر افات المعيارية لمجالات الدراسة، الصف الثامن (ن= 192)، الصف التاسع (ن=185)

\begin{tabular}{|c|c|c|c|c|c|}
\hline مستوى الأداء & الانحر افياري & الحتوسطي الحسبي & الصف & المجال & م \\
\hline عالٍ & $\cdot, 949$ & $\Gamma, Y \vee \wedge$ & الثامن & \multirow{2}{*}{ أولا: السمات الثخصية } & \multirow{2}{*}{1} \\
\hline عالِ & •, & r, ז & التاسع & & \\
\hline متوسط & $\cdot, \vee \wedge \wedge 9$ & $r, \wedge$. & الثامن & \multirow{2}{*}{ ثانيا: تتفيذ التدريس } & \multirow{2}{*}{ r } \\
\hline متوسط & $\cdot, \vee \wedge$. & $r, \cdot \leq T$ & التاسع & & \\
\hline متوسط &., 949 & $r, I Y I$ & الثامن & \multirow{2}{*}{ ثالثًا: تقويم الطالبات } & \multirow{2}{*}{$r$} \\
\hline متوسط & . & $\Gamma, Y)$. & التاسع & & \\
\hline
\end{tabular}

يتضح من جدول (2) أن المتوسط الحسابي لمجـال السـمات الثخصية المهنيـة لمعلمـات الرياضيات للصف الثامن بلغ (3.278)، وبلغ (3.367) لمعلمـات الصـف التاسـع، مـن منظور طالبـات الصف الثنامن والتاسـع، وهو متوسط حسـابي عـالٍ، وجـاء بالترتيب

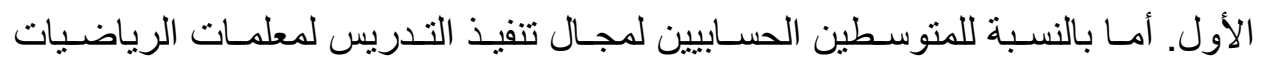
للصفين الثامن و التاسع، فقد حصلا على مسـتوى أداء متوسط، حيث بلغـت المتوسطات الحسابية (3.08، 3.046) من منظور طالبات الصفين الثامن والتاسـع على الترتيب.

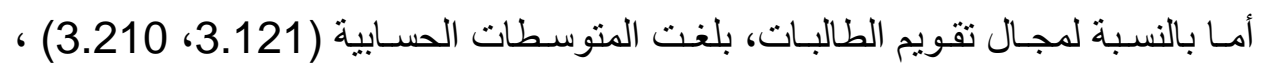
و هو تقدير أداء منوسط بالنسبة لمعلمـات الصفين الثـامن والتاسـع على الترتيب، وبهذا يكون ترتيب مجال تتفيذ التدريس الأخير. و هذا يفسر بان الطالبات يواجهن تدني لمستوى 
تقويم أداء معلمات الرياضيات من وجهة نظر طالبات المرحلة المتوسطة بدولة الكويت

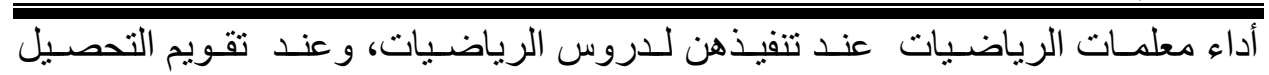
الدراسي لهن ، مما يؤدي إلي عدم التميز والانجاز في مادة الرياضيات.

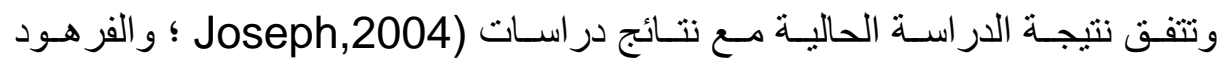
،2008 ؛ و الدهش ، 2009) و التي توصلت نتائجها إلى ضـعف المهارات التدريسية، وتقويم الطلبـة لـدى معلمي الرياضـيات. و اختلفت مـع در اسـة الحباثـنـة (2013) التـي أظهرت أن مستوى الأداء التدريسي والتقويم المتبع لمعلمي الرياضيات كان مرتفعاً. ولمعرفة واقع عبار ات كل مجال من مجالات الدراسـة، سـوف يتم التركيز على كل مجال على حده. أو لاً: مجال السمات الثخصية المهنية لمعلمات الرياضيات: تم حسـاب المتوسطات الحسـابية و الانحر افـات المعياريـة لكل عبـارة متعلقـة بالسـمات الثخصية المهنية، من وجهة نظر طالبـات الصفين الثامن و التاسـع، جدول (3) يوضـح ذلك.

جدول (3) المتوسـطات الحسـابية والاتحرافـات المعياريـة ومسـتوى الأداء لعبـارات السمات الشخصية المهنية لمعلمات الرياضيات. الثامن (ن)=192 ،التاسع(ن)=185

\begin{tabular}{|c|c|c|c|c|c|}
\hline الأداءى & الالنحر افياري & الحستوسطي & الصف & 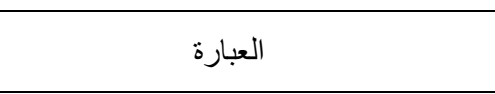 & r \\
\hline متوسط & $1, .90$ & $r, r \leq$. & 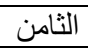 & \multirow{2}{*}{ تهتم بمظهر ها الشخصي } & \multirow{2}{*}{1} \\
\hline عالٍ & $1, \ldots v$ & $r, r \circ V$ & التاسع & & \\
\hline متوسط & $1,1 \cdot r$ & $r, Y) \leq$ & الثامن & \multirow{2}{*}{ تحرياضيات على استخدام ألفاظ مهذبة في حصة } & \multirow{2}{*}{ r } \\
\hline عالٍ & $\cdot, 90 \leqslant$ & $\Gamma, \varepsilon \Gamma \wedge$ & 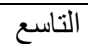 & & \\
\hline عالٍ & $1,1 M 7$ & $r, r 00$ & الثامن & \multirow{2}{*}{ تحترم شخصية كل طالبة في الصف } & \multirow{2}{*}{$r$} \\
\hline عالِ & $1, .77$ & $r, r \vee T$ & التاسع & & \\
\hline متوسط & $1,1 \Gamma \wedge$ & $r, I V r$ & الثامن & \multirow{2}{*}{ تتميز بالبشاشة وسعة الصدر } & \multirow{2}{*}{$\varepsilon$} \\
\hline متوسط & $1, .9 \leq$ & $r, 1 \wedge 9$ & التاسع & & \\
\hline عالٍ & $\cdot, 9 \cdot r$ & $r, 00 r$ & الثامن & \multirow{2}{*}{ تحضر الحصة في وقتها المحدد } & \multirow{2}{*}{0} \\
\hline عالٍٍ & $\cdot, \wedge \mid V$ & $r, 0 \wedge \varepsilon$ & التاسع & & \\
\hline عالٍ & $1, .07$ & $r, Y \wedge l$ & الثامن & \multirow{2}{*}{ تتعامل مع الطالبات بأخلاق راقية } & \multirow{2}{*}{7} \\
\hline عالِّ & $\cdot, 994$ & $r, r v r$ & التاسع & & \\
\hline متوسط & 1,114 & $r, r T \leq$ & الثامن & \multirow{2}{*}{ تطبق العدالة عند تعاملها مع الطالبات } & \multirow{2}{*}{ V } \\
\hline عالٍ & $1, \cdot Y r$ & $r, r 01$ & 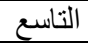 & & \\
\hline
\end{tabular}

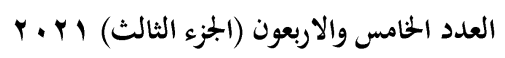
(304) جلة كلية التربية- جامعة عين شمس 
لد إسم محمد التمار

يتضـح مـن جـدول (3) أن أغلب عبـار ات مجـال السـمات الثخصـية المهنيـة لمعلمـات

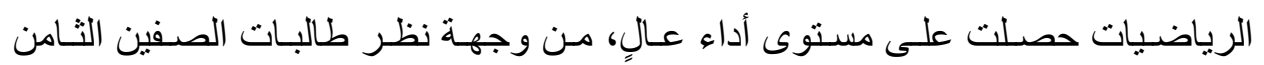
و التاسع، حيث نر اوحت المتوسطات الحسابية بين (3.255 - 3.584). أمـا العبارة " تتميز المعلمة بالبشانشة وسعة الصدر"، حصلت على تقدير أداء متوسط، من وجهة نظر

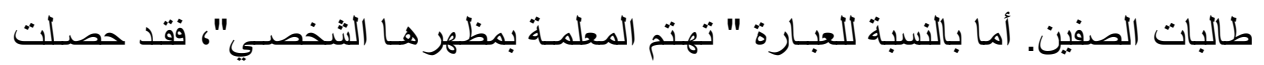

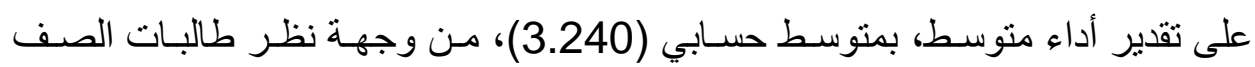
الثامن ،وحصلت علي تقدير أداء عـال، بمتوسط حسـي (3.357)، مـن وجهـة نظـر

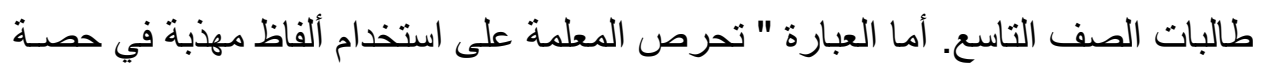
الرياضيات "، فقد حصلت على تقدير أداء متوسط، بمتوسط حسـابي (3.214)، مـن وجهة نظر طالبات الصف الثامن، بينما حصلت العبارة على درجة تقدير عالية، بمتوسط حسابي (3.438)، من وجهة نظر طالبات الصف التاسع. وكذلك بالنسبة للعبارة " تطبق المعلمة العدالة عند تعاملها مع الطالبات ".

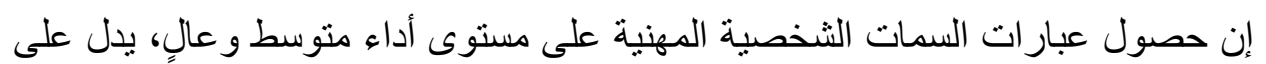

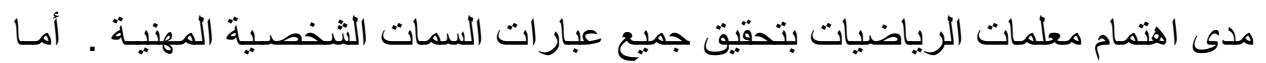
بالنسبة إلى حصول معلمة الرياضيات على مستوى أداء متوسط للعبار ات المذكورة، مـن

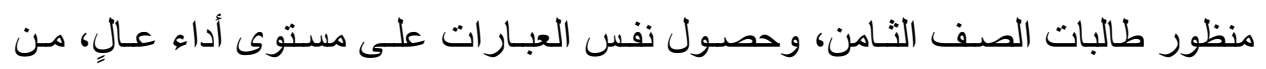

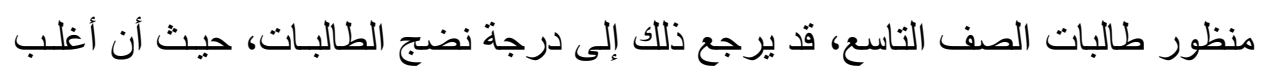

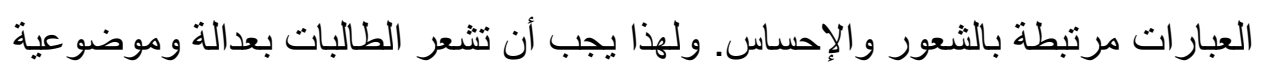

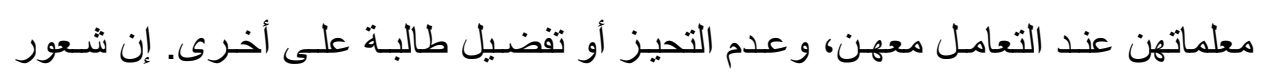
الطالبات بعدم العدالة في المعاملة قد يسبب الكر اهيـة و الحســ و الحقد بين الطالبـات. أمـا

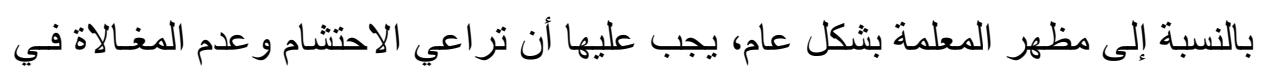

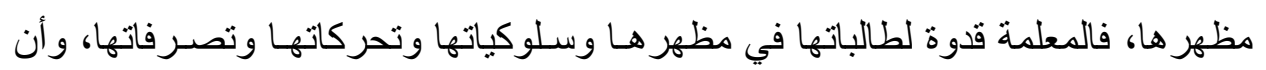
تستخدم الألفاظ المهذبة. أما بالنسبة إلى حصـول معلمـات الرياضيات على مستوى أداء 


\section{تقويم أداء معلمات الرياضيات من وجهة نظر طالبات المرحلة المتوسطة بدولة الكويت}

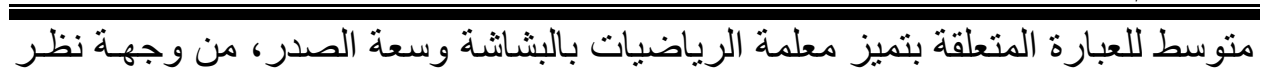

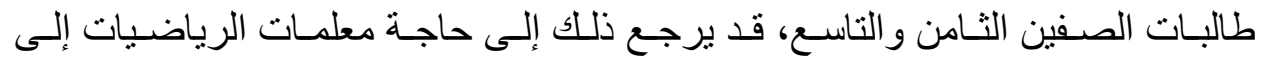

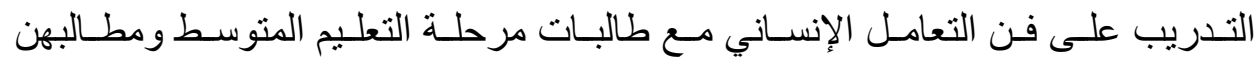
وحاجاتهن العمرية التي تنعكس على تصرفاتهن. ولهذا يجب أن تُشعر معلمة الرياضيات طالباتها بمدى اهتمامها بهن، وخاصة أنها تتعامل مع مجمو عة طالبات بفروق فردية مـن خلال عو امل نفسية واجتماعية متباينة .

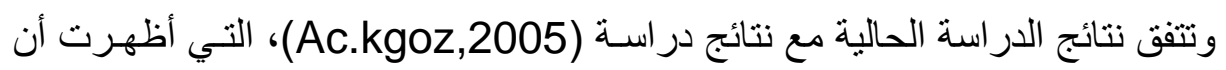

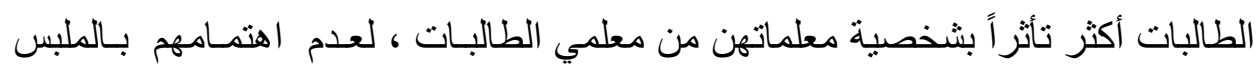

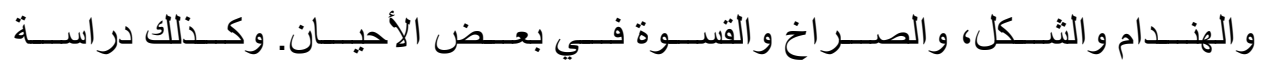
(Yesildere,2017) علاقتــه إيجابيـة مـع الطلبـه، ويتميـز بالصـبر و الهـدو و ولا يغضــب بسـرعة. ودر اسـة (Akbas,Murat and Esra,2019) الصفوف الدراسية بما يتعلق بمستويات تفكير هم وحاجاتهم. ثانيا: مجال تثفيذ التدريس لمعلمات الرياضيات: يتناول هذا المجال دراسة المحاور التاليـة: المحسور الأول: تـدريس المفـاهيم والمعلومـات الرياضية ؛ المحول الثاني: تدريس المهارات الرياضية ؛ المحور الثالث: تنميـة التفكير

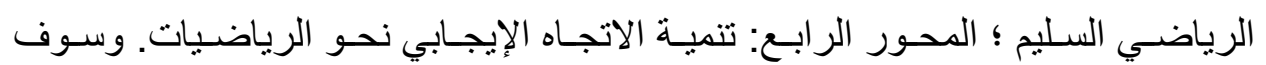
توضح عبار ات المحاور الأربعة في الجداول التالية (4 ،5، 6، 7) المحور الاول : تدريس المفاهيم والمعلومات الرياضية : تم حساب المتوسطات الحسابية و الانحر افات المعيارية ومستوى أداء معلمات الرياضيات لكل عبارة متعلقة بمحور تدريس المفاهيم و المعلومات الرياضية لطالبات الصفين التنامن و التاسع ، من وجهة نظر الطالبات أنفسهن. جدول (4) يوضح ذلك. 
لد . داسم محمد التمار

جدول (4) المتوسطات الحسابية والانحرافات المعيارية ومستوى أداء معلمات

الرياضيات لمحور تدريس المفاهيم والمعلومات الرياضية الصف الثامن (ن=192)

الصف التاسع (ن=185)

\begin{tabular}{|c|c|c|c|c|c|}
\hline مستوى الأداء & المعياري & الحستب المتي & الصف & 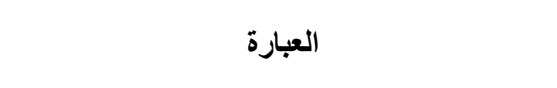 & p \\
\hline عالٍ & $\cdot, 917$ & $\Gamma, \varepsilon \cdot 1$ & 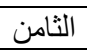 & \multirow{2}{*}{ تحرص على أن نفهم مو اضيع الرياضيات } & \multirow{2}{*}{1} \\
\hline عالٍ & $\cdot, 947$ & $r, 9 r \varepsilon$ & 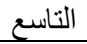 & & \\
\hline متوسط & $1, \cdot r$ & $r, 191$ & 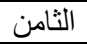 & \multirow{2}{*}{ تعضي لدينا معرفة أن مواضيع. الرياضيات تكمل } & \multirow{2}{*}{ r } \\
\hline عالٍ & $\cdot, 9 \mathrm{~V}$ & r, YOS & 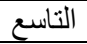 & & \\
\hline متوسط & 1,110 & $r, 9 \cdot 7$ & 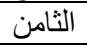 & \multirow{2}{*}{ توضح لنا أهمية الرياضيات في حياة الإنسان } & \multirow{2}{*}{ r } \\
\hline متوسط & $1, Y \cdot 9$ & $r, V Y \leq$ & 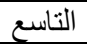 & & \\
\hline منخفض & $1, \pi 01$ & $r, \Sigma / Y$ & 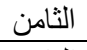 & \multirow{2}{*}{ تستخدم التكنولوجيا في دروس الرياضيات } & \multirow{2}{*}{$\varepsilon$} \\
\hline متوسط & $1, \pi) \wedge$ & T,TOE & 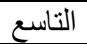 & & \\
\hline عالٍ & $\cdot, \wedge \leqslant \wedge$ & $r, 07 r$ & 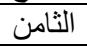 & \multirow{2}{*}{ لتستخدم الصور فو والرسومات البيانية و والجداول } & \multirow{2}{*}{0} \\
\hline عالٍ & $\cdot, v 00$ & $r, 0 \wedge \varepsilon$ & 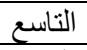 & & \\
\hline متوسط & $1, Y \cdot \leq$ & r,VqV & 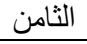 & \multirow{2}{*}{ تلتوع من طرق تدريسها عند شرح مواضيع } & \multirow{2}{*}{7} \\
\hline متوسط & $1, Y \cdot V$ & $r, 0 \leq 1$ & 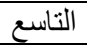 & & \\
\hline متوسط & $1,1,0$ & $r, 9 r \wedge$ & الثنامن & \multirow{2}{*}{ توفر لنا بيئة صفية مناسبة لتعليم الرياضيات } & \multirow{2}{*}{ V } \\
\hline متوسط & $1,1 \ldots$ & $r, \cdot \lambda v$ & 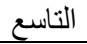 & & \\
\hline متوسط & $1,11 r$ & $r, q .7$ & الثامن & \multirow{2}{*}{ تعلم الرياضيات المواد المتاحة في الصف لمساعدتنا على } & \multirow{2}{*}{$\Lambda$} \\
\hline متوسط & $1,1 Y K$ & $r, q \cdot r$ & التاسع & & \\
\hline متوسط & $1, .19$ & $r, 14 q$ & الثامن & \multirow{2}{*}{ تشارك في اختبار الأنشطة الرياضية } & \multirow{2}{*}{9} \\
\hline متوسط & $1, .79$ & $r, 119$ & التاسع & & \\
\hline عالٍ & $\leq, \cdot 1 \leq$ & $r, r \cdot r$ & الثامن & \multirow{2}{*}{ تابتابع معرفة ماذا فههنا من معلومات في دروس } & \multirow{2}{*}{1.} \\
\hline عالٍ & $\cdot, 9 \leq 0$ & $r, r \circ V$ & التاسع & & \\
\hline متوسط & $1, \cdot \varepsilon \cdot$ & $r, 19 \Lambda$ & الثامن & \multirow{2}{*}{ تشرح لولي الامر انجازي في الرياضيات } & \multirow{2}{*}{11} \\
\hline متوسط & $1, \cdot \wedge 7$ & $r, 17 r$ & التاسع & & \\
\hline
\end{tabular}

يتضح من جدول (4) أن أغلب عبار ات محور تدريس المعلومات والمفـاهيم الرياضـية

حصـلت على متوسـطات حسـابية تر اوحـت بـين(2.541 - 3.934)، بمسـتوى أداء

(متوسط - عالٍ)، من وجهة نظـر طالبـات الصـفين الثـامن والتاسـع، وحصـلت العبـا رة "تحرص معلمة الرياضيات على أن نفهم مو اضيع الرياضـيات"، على أعلى متوسـي حسـابيين (3.4013 3.934)، وبمسـتوى أداء عـالٍٍ، مـن وجهـة نظـر طالبـات الصـفين

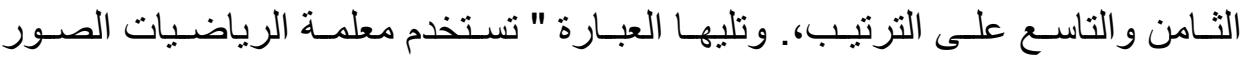

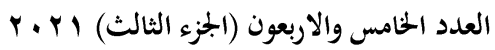

(307)

جلة كلية التربية- جامعة عين شمس 


\section{تقويم أداء معلمات الرياضيات من وجهة نظر طالبات المرحلة المتوسطة بدولة الكويت}

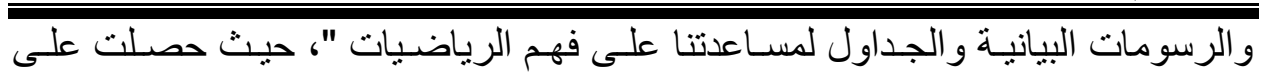
متوسطي حسابيين (3.563 ، 3.584)، بمستوى أداء عالٍٍ . إلا أن الملاحظ بأن العبارة

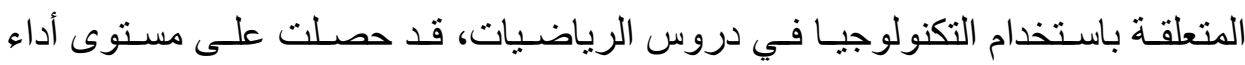
(منخفض)، بمتوسط حسابي (2.412) من وجهة نظر طالبات الصف الثامن، وبمسـتوى أداء (متوسط)، من وجهة نظر طالبات الصف التاسع. إن حصول جميع عبار ات مجال تدريس المفاهيم والمعلومات الرياضية على مستوى مئو متوسط و عال، يدل على مدى اهتمام معلمات الرياضيات بتوظيف محتوى العبار ات إلى مادة تدريسية للإرتقاء بمسـتوى إنجـاز الطالبـات في مـادة الرياضـيات. أمـا بالنسبة إلى لى حـرص معلمـات الرياضـيات على أن تفهم طالبـاتهن مو اضـيع الرياضـيات مـن خـلال استخدام الصور و الرسومات البيانية الجداول، يمكن تفسير ذلك بـأن معلمـات الرياضيات

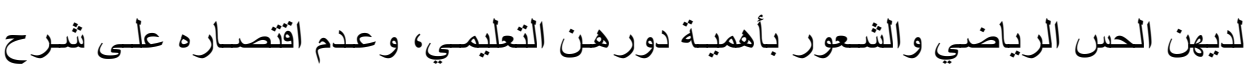
ونقل وتوصيل محتوى الكتاب المدرسي للطالبات. أما بالنسبة للعبار ات المتعلقة بتوضيح أهمية الرياضيات في الحياة، و التتوع في طرق التدريس، وتوفير بيئة تعليميـة مناسبة

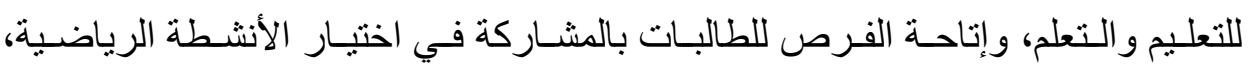

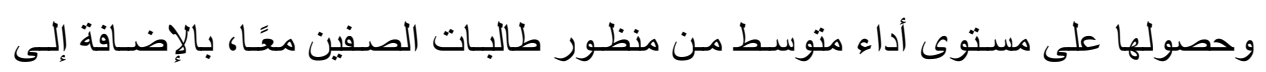

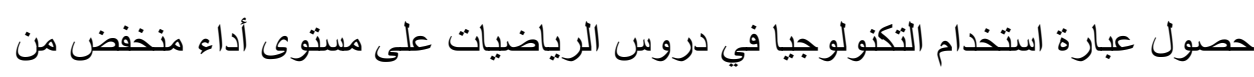
منظور طالبات الصف الثامن، وقد يفسر ذلك بمحدودية معرفة المعلمات للمعايير المهنيـة العالمية لتدريس الرياضيات ،وحاجة معلمات الرياضيات إلى تطوير مهار اتهن التدريسية

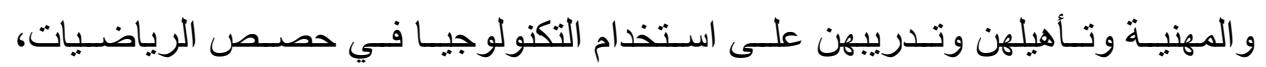
و التدريب على استخدام طرق تدريس حديثة في تعليم الرياضيات، ومعرفـة مدى أهميـة توفير بيئة صفية فاعلة لتعليم وتعلم الرياضيات. 


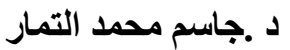

وتتفق نتائج الدر اسة الحالية مع نتائج در اسة (Yesildere,2017) و التي أظهرت أن معلم الرياضيات الجيد يجب أن ينوع من طرق تـدريس الرياضيات، و أهميـة ربط مـادة الرياضيات بأمثلة من و اقع الحياة اليومية. واختلفت مع در اسة كل من (الدهش، 2009 ؛ النذير،2004) التي توصلت نتائجهما إلى أن قدرة معلمي الرياضيات على تـوفير بيئة صفية مشجعة على التعلم كانت ضـعيفة، وكذلك استخدام معلمي الرياضيات للمداخل

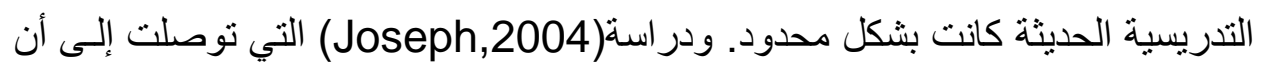
المعلمين لا يحققون مسـتوى عـالٍ مـن المعرفـة حـول اسـتخدام المعـايير الصـادرة مـن

.(NCTM,1991)

المحور الثاني :تدريس المهارات الرياضية

تم حساب المتوسطات الحسابية والانحر افات المعيارية ودرجـة أداء معلمـات الرياضـيات لعبار ات محور تدريس المهار ات الرياضية لطالبات الصفين الثامن و التاسـع، مـن وجهـة نظر الطالبات أنفسهن. جدول (5) يوضح ذللك. جدول (5) المتوسطات الحسابية والانحرافات المعيارية ومستوى أداء معلمات الرياضيات محور تدريس المهارات الرياضية الصف الثامن (ن=192) ،الصف التاسع (ن=185)

\begin{tabular}{|c|c|c|c|c|c|}
\hline مستوى الأداء & المعياري & الحستوسطي & الصف & 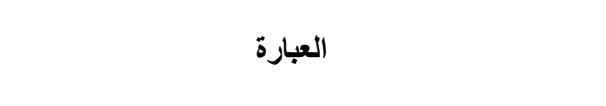 & r \\
\hline متوسط & $1, .11$ & $r, 1 \wedge \wedge$ & 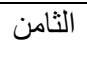 & \multirow{2}{*}{ تشجعنا على ربط أفكار الرياضيات مع بعضها البعض } & \multirow{2}{*}{1} \\
\hline متوسط & $\cdot, 999$ & $r, r \ldots$ & التاسع & & \\
\hline متوسط & $\cdot, 971$ & $r, r \backslash q$ & 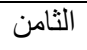 & \multirow{2}{*}{ تدربنا على تطبيق خطوات حل المشكلات الرياضية } & \multirow{2}{*}{$r$} \\
\hline 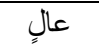 & $\cdot, 9 \wedge \wedge$ & r,Y.. & 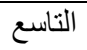 & & \\
\hline متوسط & 1,09 & $r, 1 \leq \tau$ & 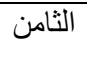 & \multirow{2}{*}{ تدربنا على إعطاء السبيية في الرياضيات. } & \multirow{2}{*}{ r } \\
\hline منوسط & $1, \cdot Y 7$ & r,i ro & 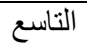 & & \\
\hline 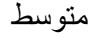 & $1, \cdot 1 \varepsilon$ & $r, Y) \leqslant$ & 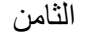 & \multirow{2}{*}{ تتمي لدينا مهارات الحس الرياضي مثل (التقدير .) } & \multirow{2}{*}{$\varepsilon$} \\
\hline متوسط & $1, \cdot \wedge \varepsilon$ & $r, \cdot r$ & 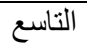 & & \\
\hline متوسط & $1, \cdot \leq V$ & $r, I \vee r$ & 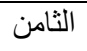 & تدربنا على أسلوب الحوار والمناقثة في الرياضيات & 0 \\
\hline
\end{tabular}

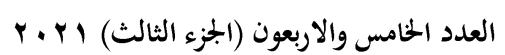

(309)

مجلة كلية التربية- جامعة عين شثس 
تقويم أداء معلمات الرياضيات من وجهة نظر طالبات المرحلة المتوسطة بدولة الكويت

\begin{tabular}{|c|c|c|c|c|c|}
\hline متوسط & $1, \cdot 4$ & $r, r_{\ldots}$ & 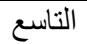 & & \\
\hline متوسط & $1,1 \pi$ & $r, \cdot, r$ & 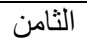 & \multirow{2}{*}{ تنمي لدينا القدرة على الاستماع لبعضنا البعض } & \multirow{2}{*}{7} \\
\hline متوسط & 1,171 & $r, \cdot r V$ & 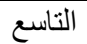 & & \\
\hline متوسط & $1, \cdot \leqslant 1$ & $r, Y, 9$ & 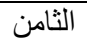 & \multirow{2}{*}{ تشجعنا على التفاعل معها عن طريق طرح الأسئلة } & \multirow{2}{*}{ V } \\
\hline عالٍ & $1, \cdots$ & r,YOS & 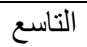 & & \\
\hline متوسط & $1, \cdot \varepsilon \cdot$ & $r, 17 V$ & 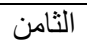 & \multirow{2}{*}{ تساعدنا على صياغة الأسئلة الرياضية } & \multirow{2}{*}{$\wedge$} \\
\hline متوسط & $1, .71$ & $r, \cdot r r$ & 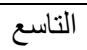 & & \\
\hline 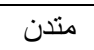 & $1, \pi 4 \Lambda$ & 1,819 & 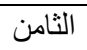 & \multirow{2}{*}{ تشجعنا على استخدام الآلة الحاسبة } & \multirow{2}{*}{9} \\
\hline متدن & $\cdot, 9 \wedge r$ & $1,0 \cdot 1$ & التاسع & & \\
\hline متوسط & 1,109 & $r, 0 \vee 9$ & 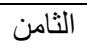 & \multirow{2}{*}{ تقوم بتمثيل المو اقف الرياضية بمشاركة بعض الطالبات } & \multirow{2}{*}{1.} \\
\hline متوسط & $1, Y 07$ & r,or. & 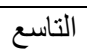 & & \\
\hline منوسط & $1, .77$ & $\Gamma, 1 \leqslant$. & الثامن & \multirow{2}{*}{ تتابع ما اكتسبه الطالبات من مهار ات رياضية } & \multirow{2}{*}{11} \\
\hline متوسط & $1, \cdot 1 \mathrm{~V}$ & $r, 1 \wedge 9$ & 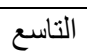 & & \\
\hline عالٍ & $1, \cdot 11$ & $r, r \vee T$ & 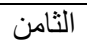 & \multirow{2}{*}{ تدرسنا مادة الرياضيات بأسلوب سهل ومتسلسل ومنظم } & \multirow{2}{*}{ ir } \\
\hline متوسط & $1,1 \cdot 1$ & $r, 190$ & 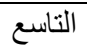 & & \\
\hline متوسط & $1,1 \leqslant$ & $r, \cdot 7 \Lambda$ & 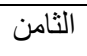 & \multirow{2}{*}{ تدربنا على البحث و الاستكثاف في دروس الرياضيات } & \multirow{2}{*}{ Ir } \\
\hline متوسط & $1,1 \times 9$ & $\Gamma, \cdot T$. & 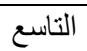 & & \\
\hline
\end{tabular}

يتضح من جدول (5) أن أغلب عبـار ات محور تدريس المهار ات الرياضية لطالبـات الصفين الثامن والتاسع حصلت على مستوى أداء متوسط ، مـن وجهـة نظر الطالبـات

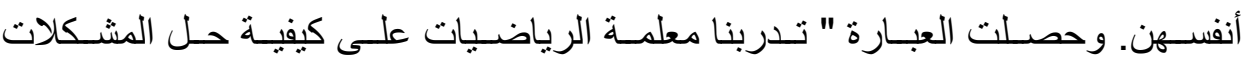
الرياضية"، على منوسط حسابي (3.26)، بمستوى أداء عالٍ ، من وجهة نظر طالبـات الصف التاسع ،بينما حصلت هذه العبارة على مسـتوى أداء متوسط، بمتوسط حسـابي (3.219)، من وجهة نظر طالبات الصف الثامن، وكذلك بالنسبة للعبارة "تشجعنا معلمـة الرياضيات على التفاعل معها عن طريق طرح الأسئلة و الإجابـة عليهـا " ،فقد حصلت فئل على مستوى أداء عالٍ ، بمتوسط حسابي (3.254)، من منظور طالبات الصف التاسـع،

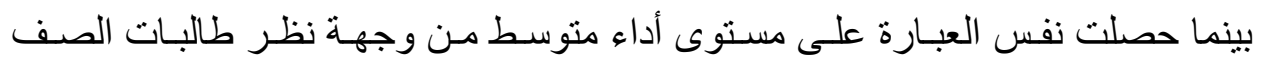
الثامن ،. بمنتوسط حسابي (3.219). بينما حصلت العبارة " تثـجعنا معلمـة الرياضـيات

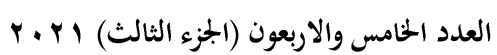
(310) مجلة كلية التربية- جامعة عين شمس 
لـ إسم محمد التمار

على استخدام الآلة الحاسبة "، فقد حصلت على مستوى أداء متـدنٍ مـن منظور طالبـات الصفين الثامن و التاسع، بمتوسطين حسابيين (1.719، 1.508) على الترتيب. إن حصول جميع العبار ات على مستوى أداء منوسط و عال، ما عدا عبارة واحده، يدل على مدى حرص معلمات الرياضيات بتطبيق مضمون العبار ات عند تدريس المهارات الرياضية، مما انعكس أثره الإيجابي على تعلم الطالبات للمهار ات الرياضية. أمـا بالنسبة لحصول عبار ات" تشجيع الطالبات على ربط الأفكار الرياضية، وتنميـة مهار ات الحس الرياضي، ومساعدة الطالبات على صياغة الأسئلة الرياضية، وقيـام معلمـة الرياضيات

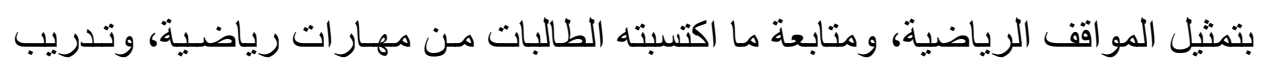

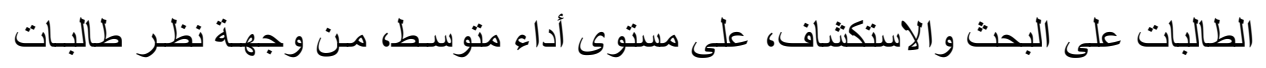
الصفين الثامن و التاسع، يدل على أن الأداء التدريسي لمعلمات الرياضيات متقارب جدًا عند تدريس المهارات الرياضية لطالبات الصفين، دون مر اعـاة لمسـتوى النضـج العقلي و الفارق الأكاديمي بين طالبات كل صف دراسي. و هذا يدل على عدم مر اعـاة معلمـات الرياضيات لمستوى صفوف المرحلة المتوسطة عند تدريس الرياضيات ، وخاصة عندما يتكرر ذللك في أغلب جداول الدراسـة، وهذا يؤكد على حاجـة معلمـات الرياضـيات

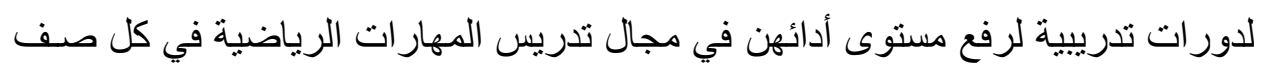
دراسي، وتمكينهم من هذه المهار ات لتحسين مستوى تعلم وتمّكن الطالبات من المهار ات

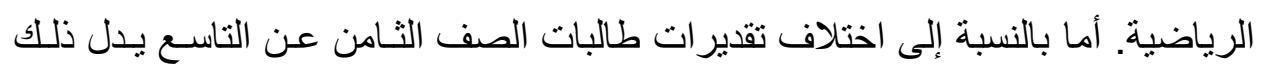

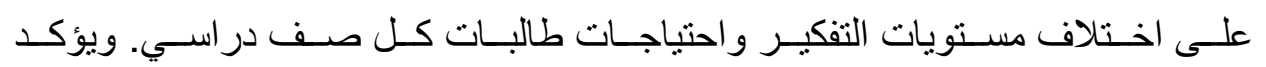
(Hardi,et al ,2021) على أن أداء معلم الرياضيات يعد دافعًا قويًَا للطلبـة ليكونـوا من المتميزين في الرياضيات. أما بالنسبة لعدم تتجيع معلمات الرياضيات على استخدام

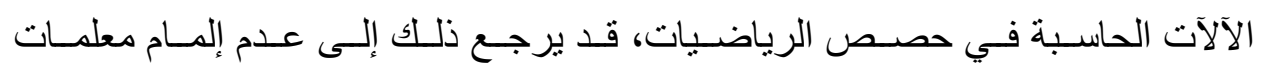

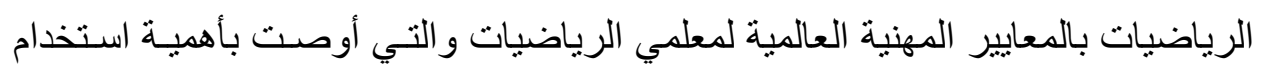
الآلآت الحاسبة والحاسوب لإثراء بيئة تعلم الرياضيات (NCTM,1991).

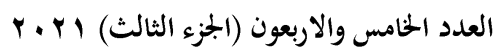

(311)

مجلة كلية التربية- جامعة عين شثس 


\section{تقويم أداء معلمات الرياضيات من وجهة نظر طالبات المرحلة المتوسطة بدولة الكويت}

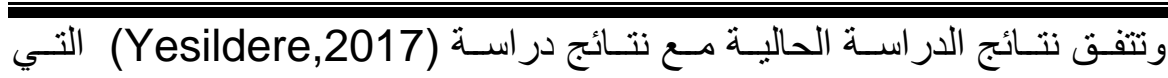

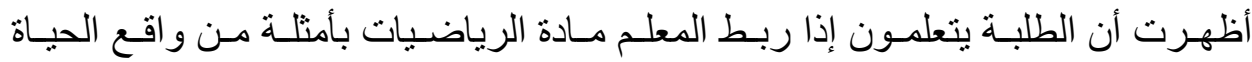
اليومية. وكذلك مع ما نـادى بـه NCTM حـول أهميـة إثـارة المتعلمين لممارسـة تـر ابط الأفكار الرياضية وحل المشكلات الرياضية، وتثـجيع المتعلمين على طـرح الأسئلة. وتختلف نتائج الدراسة الحالية مع دراسة النذير (2004) التـي أظهرت ضـعف مسـتوى تمكـن معلمسي الرياضـيات مـن المهـار ات الرياضـية في المرحلـة المتوســة. ودر اسـة

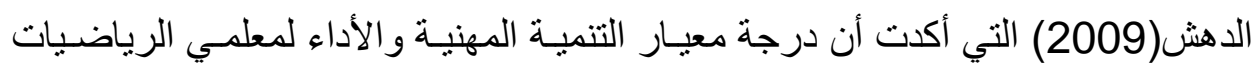

كان ضعيفًا.

\section{المحور الثالث :تنمية التفكير الرياضي السليم}

تم حساب المتوسطات الحسابية و الانحر افات المعيارية ومستوى أداء معلمات الرياضيات لعبار اتُمحو. تنمية التفكير الرياضي لطالبات الصفين الثامن و التاسـع، مـن وجهة نظر الطالبات أنفسهن، جدول (6) يوضح ذلك.

جدول (6) المتوسطات الحسابية والانحرافات المعيارية ومستوى أداء معلمات الرياضيات لمحور تنمية التفكير الرياضي لاي الطالبات الصف الثامن (ن=192)،الصف التاسع (ن=185)

\begin{tabular}{|c|c|c|c|c|c|}
\hline مستوى الاداء & 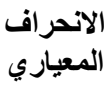 & الحسابي & الصف & 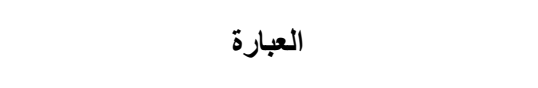 & b \\
\hline عالٍ & 0.914 & 3.385 & 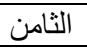 & \multirow{2}{*}{ تحرصيات على تطوير قدراتنا على التفكير في } & \multirow{2}{*}{1} \\
\hline متوسط & 0.993 & 3.238 & 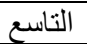 & & \\
\hline عالٍ & 0.927 & 3.401 & 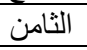 & \multirow{2}{*}{ تطرح أسئلة متنو عة تحتاج إلى تفكير رياضى } & \multirow{2}{*}{ r } \\
\hline عالٍ & $\cdot, 9 \cdot V$ & ס ס & 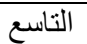 & & \\
\hline عالٍ & $\cdot, 9 \wedge r$ & r, roq & 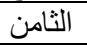 & \multirow{2}{*}{ تالإجابةنا بالتدرج في تحليل السؤال للوصول إلى } & \multirow{2}{*}{$r$} \\
\hline عالٍ & $1, \cdot Y 1$ & 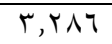 & 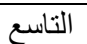 & & \\
\hline متوسط & $1,1 \leq \varepsilon$ & $r, \cdot \vee q$ & 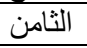 & \multirow{2}{*}{ تحفزنا على حل المشكلات الرياضية } & \multirow{2}{*}{$\varepsilon$} \\
\hline متوسط & $1, \cdot \wedge \leq$ & $r, q \leq 1$ & 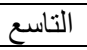 & & \\
\hline عالٍ & $1, .17$ & r, rוT & 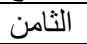 & \multirow{2}{*}{ تدربنا على إثبات صحة الإجابة على السؤال } & \multirow{2}{*}{0} \\
\hline عالٍ & $\cdot, 9 \vee \wedge$ & $r, r, q$ & 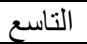 & & \\
\hline متوسط & $1, \cdot \leq V$ & $r, .0 r$ & 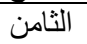 & تستخدم الوسائل التعليمية و التكنولوجية لتساعدنا & 7 \\
\hline
\end{tabular}

العدد الخامس والاربعون (الجزء الثالث) ب r.r 
لد .جاسم محمد التمار

\begin{tabular}{|c|c|c|c|c|c|}
\hline منوسط & $1,1, r$ & $r, \cdot r \hat{~}$ & 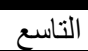 & على التفكير في المو اقف الرياضية & \\
\hline متوسط & $1, \cdot \sqrt{1,7}$ & r, Y, & 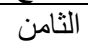 & \multirow{2}{*}{ توفاعدنا على الإبداع والأنشطة الرياضية المتنوعة التي } & \multirow{2}{*}{$v$} \\
\hline منوسط & $1, \cdot r_{0}$ & $r, 1 \leq 7$ & التاسع & & \\
\hline متوسط & 1,00 & $r, \cdot r t$ & 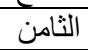 & \multirow{2}{*}{ تتيح لنا الوقت الكافي للتفكير و الاكتشاف } & \multirow{2}{*}{$\wedge$} \\
\hline متوسط & $1, \cdot \leq 7$ & $r, .9 r$ & التاسع & & \\
\hline
\end{tabular}

يتبين من جدول (7) أن أغلب عبار ات تنمية التفكير الرياضي لاى الطالبات قد حصلت

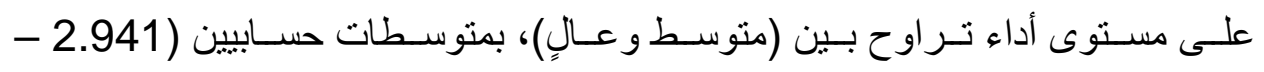
3.401). وحصلت العبارة " تطر ح معلمة الرياضيات أسئلة متنوعـة تحتـاج إلى تفكير رياضي " على مستوى أداء عالٍ، بمتوسطين حسابيين (3.401، ولـ 3.335)، من منظور

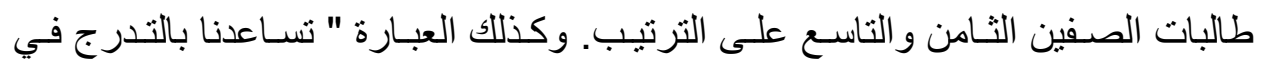

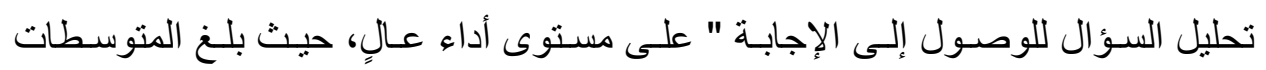
الحسابيات للعبارة (3.359 ،3.286)، من وجهة نظر طالبات الصفين الثامن و التاسـع

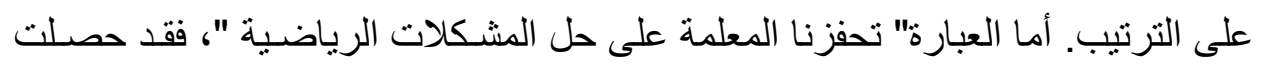

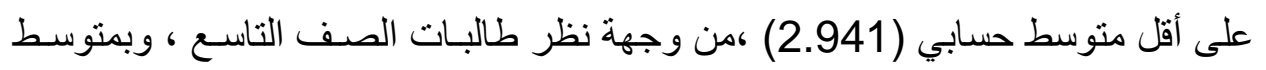
حسابي (3.079)، من وجهة نظر طالبات الصف الثامن. وحصلت باقي العبار ات على مستوى أداء متوسط، من وجهة نظر طالبات الصفين. إن حصول جميع العبار ات على منوسطات حسـابية متوسطة وعاليـة، دليـل و اضـح

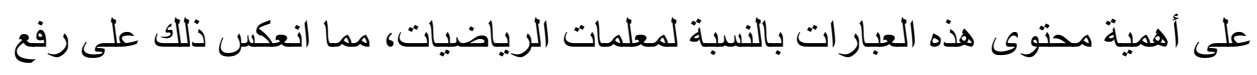

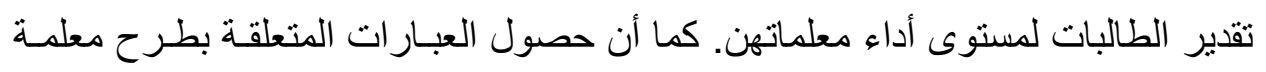
الرياضيات لأسئلة تحتاج إلى تفكير، وتحليل السؤال للوصـول إلى الحل، على مستوى ألى

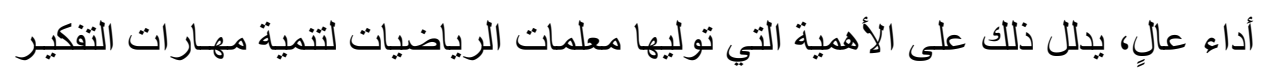
لاى الطالبات، وأن يصبحن أكثر قدرة على التحليل والتركيب والمناقتشة والنقد للمشكلات

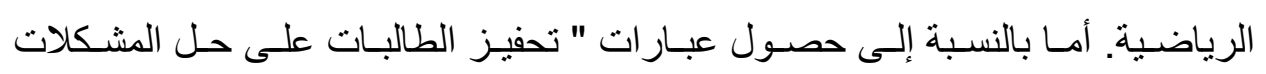

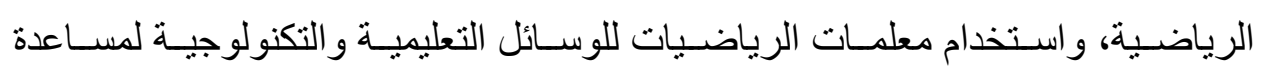

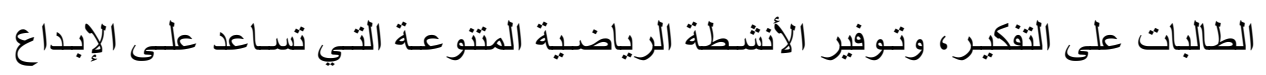


تقويم أداء معلمات الرياضيات من وجهة نظر طالبات المرحلة المتوسطة بدولة الكويت

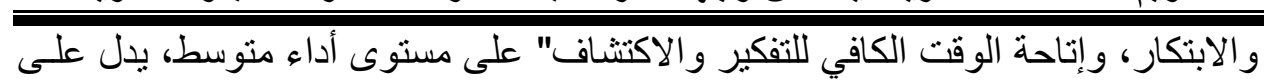

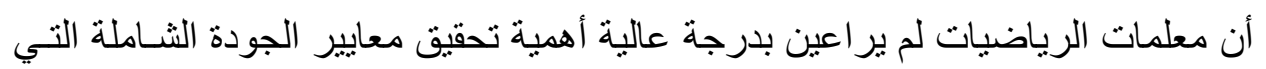

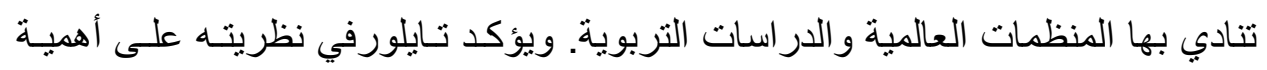
تنمية عقل الطالب من خلال المناقثة والحوار و التأمل ،وهذه تتيح للطالب فرص التفاعل مع البيئة المحلية والعالم الخارجي (زيتون وزيتون،2003).

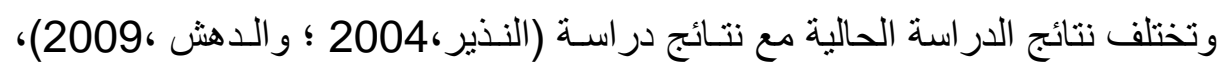
حيث أظهرت ضعف اهتمام معلمي الرياضيات بالأنشطة الإبداعية، وضـف إدارة زمن

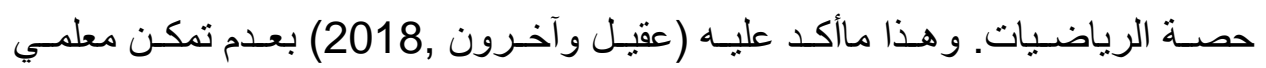
رياضيات المرحلة المتوسطة في دولة الكويت من تتمية مهار ات التفكير الناقد، وطرق

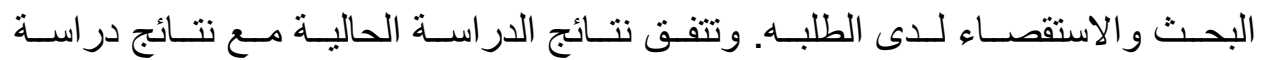

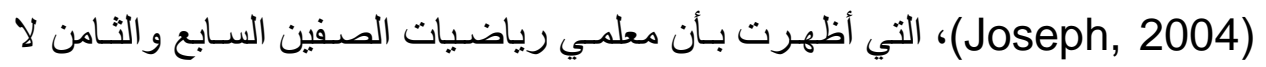
يحققون مستوى عالٍ من المعرفة حول استخدام المعايير الصادرة من NCTM. المحور الرابع :تنمية الاتجاه الإيجابي نحو الرياضيات تم حساب المتوسطات الحسابية و الانحر افات المعيارية ومستوى أداء معلمات الرياضيات لعبار ات محور تنمية الاتجاه الإيجابي نحو الرياضيات لطالبات الصفين الثـامن والتاسـع، من وجهة نظر الطالبات أنفسهن. جدول (7) يوضح ذلك. جـدول (7) المتوسـطات الحســابية والانحرافـات المعياريـة ومســتوى أداء معلمـات

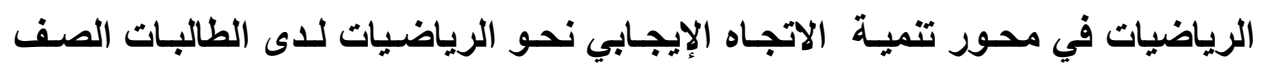
الثامن(ن=192)،الصف التاسع (ن=185)

\begin{tabular}{|c|c|c|c|c|c|}
\hline مستوى الأداء & الانحراف المعياري & الحستوسطي & الصف & العبارة & p \\
\hline متوسط & $I, r \cdot V$ & $r, \cdot V r$ & الثامن & \multirow{2}{*}{ تجعل حصة الرياضيات ممتعة } & \multirow{2}{*}{1} \\
\hline متوسط & $1,1 Y r$ & $r, \wedge 9 r$ & التاسع & & \\
\hline منوسط & $1, r \leq$. & $r, 91 r$ & الثامن & \multirow{2}{*}{ تنمي لدينا حب مادة الرياضيات } & \multirow{2}{*}{ r } \\
\hline متوسط & 1,194 & $r, V T r$ & التاسع & & \\
\hline
\end{tabular}

العدد الخامس والاربعون (الجزء الثالث) I r. r r

(314)

مجلة كلية التربية- جامعة عين شمس 
لد .جاسم محمد التمار

\begin{tabular}{|c|c|c|c|c|c|}
\hline متوسط & $1,1 \times 4$ & $r, q q$. & الثنامن & \multirow{2}{*}{ تعزز ثقتنا بانفسنا عند تعلم الرياضيات } & \multirow{2}{*}{$r$} \\
\hline متوسط & $1,1 \vee \wedge$ & $r, \wedge \wedge I$ & التاسع & & \\
\hline عالٍ & $1, \cdot \leq 7$ & r., & الثامن & \multirow{2}{*}{ تستمع إلى إجاباتنا بكل اهتمام وبصدر رحب } & \multirow{2}{*}{$\varepsilon$} \\
\hline 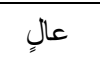 & $\cdot, 900$ & $r, r \leq \tau$ & 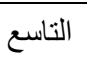 & & \\
\hline متوسط & $1, .19$ & $r, 191$ & التامن & \multirow{2}{*}{ تتيح لنا حرية اختيار الانشطة الرياضية } & \multirow{2}{*}{0} \\
\hline منوسط & $1, \cdot T V$ & $r, 119$ & التاسع & & \\
\hline
\end{tabular}

يتضح من جدول (7) أن أغلب عبـار ات تتميـة الاتجـاه الإيجـابي نحو الرياضـيات قد

حصلت على مستوى أداء متوسط، حيث تراوحت المتوسـات الحسـابية بـين(2.762 3.072)، من وجهة نظر طالبات الصفين الثامن والتاسع، ما عدا العبارة " تستمع معلمة الرياضيات إلى إجاباتتا بكل اهتمام وسعة صدر"، حيـث حصـلت على تقدير أداء عـالٍ، بمتوسطين حسابيين (3.260، 3.346)، من وجهة نظر طالبات الصفين الثامن والتاسع على الترتيب. إن حصول معلمات الرياضيات على مستوى أداء متوسط و عالٍ، يدل على أن معلمات الرياضيات يمارسـن مـا تضــنته العبـار ات عند تـدريس الرياضـيات، ولكن بدرجات متفاوتة، ويوضح ذلك مدى قناعة المعلمات بأهمية جميع العبار ات لدى طالبـات الصفين الثامن و التاسع، كما يدل ذلك على أن اتجاهـات معلمـة الرياضـيات نحـو نفسـها إيجابية مما بنعكس ذلك على تقدير الطالبات لها، ولهذا بجب أن تُشـعر المعلمسة طالباتهـا باتجاهها الإيجابي نحوهم، و إظهار مشاعر ها الإيجابية، مما يـؤثر ايجابـاً على زيـادة ثقـة الطالبـات بقدر اتهن وبأنفســـن ـ وتشـير الدراسـات التربويـة إلـى أن توقعـات المعلمين الايجابية نحو طلبتهم يزيد من دافعية الطلبة نحو التعلم (الحيلة ،1423). أما بالنسبة إلى حصول العبار ات التي تتمي لدى الطالبات حب الرياضـيات، وتعزيـز ثقة الطالبات بأنفسهن، وجعل حصص الرياضيات ممتعة، على مستوى أداء متوسط، مـن وجهة نظر طالبات الصفين الثامن والتاسع، يدل على حاجة المعلمات إلى رفع قدر اتهن لتكوين الاتجاهات الإيجابية، وتتمية ميـول الطالبـات نحو حب الرياضـيات، و الاستمتاع بها، و الإحساس بأهميتها وفائدتها في الحيـاة اليوميـة،و در اسـة الرياضـيات في السـنوات المستقبلية بنجاح. علمًا بأن تنمية الاتجـاه الإيجـابي نحو الرياضـيات، مـن أحد الأهداف 
تقويم أداء معلمات الرياضيات من وجهة نظر طالبات المرحلة المتوسطة بدولة الكويت

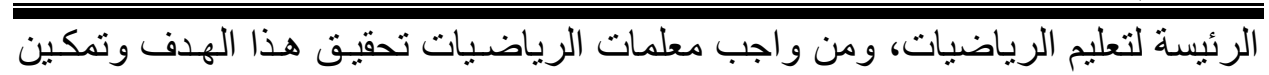

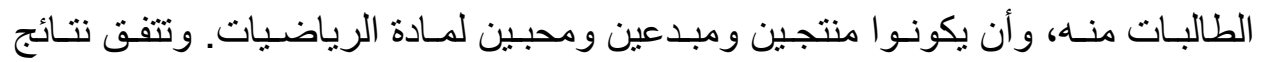
الدر اسـة الحاليـة مـع نتـائج در اســة (Yesildere,2017) ، التــي أظهـرت أن معلـم الرياضيات الجيد هو الذي يحرص على تنمية حب الرياضيات لدى طلابه. ثالثاً مجال تقويم الطالبات :

تـم اســـخدام المتوســات الحســابية و الانحر افـات المعياريــة ومسـتوى أداء معلمــات الرياضيات لعبار ات مجال تقويم المستوى التحصيلي لطالبـات الصـفين الثامن و التاسـع. جدول (8) يوضح ذللك. جدول (8) المتوسطات الحسابية والانحرافات المعيارية ومستوى الأداء لعبارات مجال تقويم الطالبات الصف الثامن (ن=192)،الصف التاسع(ن=185)

\begin{tabular}{|c|c|c|c|c|c|}
\hline مستوى الأداء & الانحراف & الحتوسط الحسبي & الصف & العبارة & p \\
\hline متوسط & $1, Y Y A$ & $r, \cdot r_{1}$ & الثامن & \multirow{2}{*}{ ملف وحو ار ، حل مشكلات رياضية، من طجرق تقويم الطالبات (ألعاب تفكير ، مناقثة عملية، عمل جماعي، } & \multirow[b]{2}{*}{1} \\
\hline متوسط & ס 1,1 & $r, 1 \leq \tau$ & التاسع & & \\
\hline 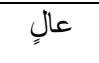 & $\cdot, 91 Y$ & $r, r r q$ & الثامن & \multirow{2}{*}{ تستخدم المعلمة الاختبار ات. التحريرية في تقويم الطالبات } & \multirow{2}{*}{$r$} \\
\hline عالٍ & $\cdot, 9.0$ & $r, r \pi r$ & التاسع & & \\
\hline 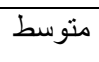 & 1,1, & $r, \cdot 19$ & 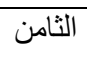 & \multirow{2}{*}{ توضح لنا المعلمة أخطاؤنا في الاختبار ات } & \multirow{2}{*}{$r$} \\
\hline متوسط & $1, \cdot 19$ & $r, Y r r$ & التاسع & & \\
\hline متوسط & $1,1 \vee r$ & $r, \mu \nu$ & الثامن & \multirow{2}{*}{ تحرص المعلمة على علاج أخطاء كل طالبة في الاختبار ات } & \multirow{2}{*}{$\varepsilon$} \\
\hline متوسط & $1, \cdot 19$ & $r_{\cdot}, q V$ & التاسع & & \\
\hline
\end{tabular}

يتضح من جدول (8) أن أغلب عبار ات مجال التقويم حصلت على متوسطات حسـابية تراوحت بين (3.021 - 3.232)، بمستوى أداء " متوسط"، مـن وجهة نظر طالبـات الصفين الثامن و التاسع، ما عدا عبارة " تستخدم المعلمة الاختبار ات التحريرية في تقويم المستوى التحصيلي للطالبات"، حيث حصلت العبارة على مستوى أداء عـالٍ، بمتوسطين 
لد .جاسم محمد التمار

حسـابيين (3.339، 3.362)، مسن وجهة نظر طالبـات الصفين الثامن و التاسـع على لـى الترتيب. إن تركيز معلمات الرياضيات على الاختبارات التحريرية لتقويم الطالبات، يدل على أن عملية التقويم لم تتم وفق استخدام طرق حديثة ومتنو عة، على عكس ما نـادت بـــ المنظمات العالمية و الدر اسات الحديثة في تقويم طلبـة الرياضيات. ولتحقيق الاتجاهـات الحديثة في تقويم طالبات الرياضيات، يجب أن تسـتخدم معلمـة الرياضيات طـرق تقويم متنو عة مثنل ألعـاب التفكير، و المناقثــة والحـوار، و التجـارب العمليـة، وحلـل المشكلات

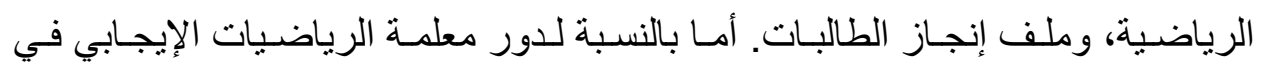

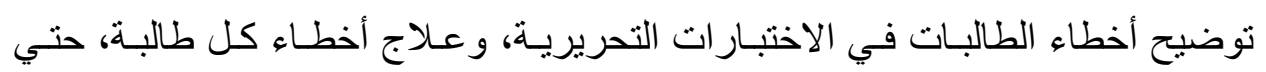
تدرك كل طالبة نقاط ضعفها ومحاولة علاجها. ولكن حصول هذه العبار ات علي مستوى أداء متوسط، مـن وجهـة نظـر طالبـات الصـف الثـامن و التاسـع، يـدل على أهميـة دعم معلمات الرياضيات بالمعلومات والمهار ات الرياضية للتركيز على تحليل الاختبـار ات

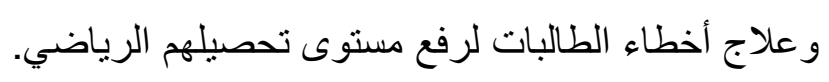

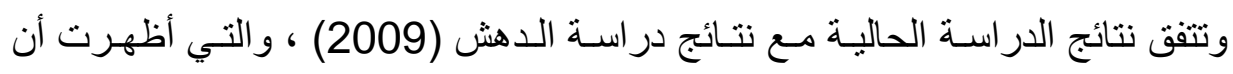
تقويم المعلمين لطلابهم لم يتم في ضو ء المعايير المهنية لتحسين أداء معلمي الرياضيات. ودر اسة النذير (2004) التي أظهرت عدم اهتمام معلمي الرياضيات بالأنشطة الإبداعيـة

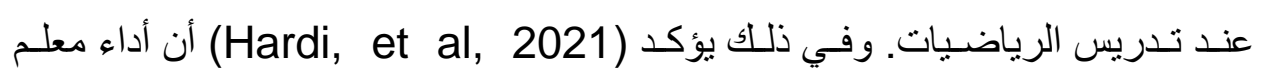

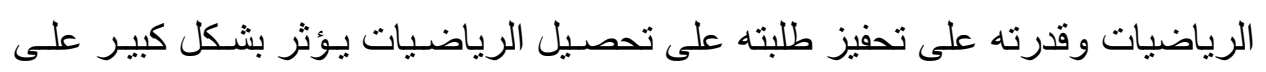
اهتمام الطلبة على التحصيل العلمي. السؤال الثاني والذي ينص على "هل تختلف آراء طالبـات الصفين الثامن والتاسـع بالنسبة لمستوي أداء معلمات الرياضيات في مجـالات (السـمات الشخصية المهنيـة ،

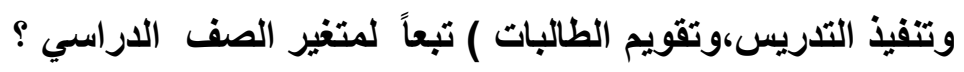
للإجابة على سؤال الدراسة الثاني تم صياغة الفرضية التالية :" لاتوجد فروق ذات دلالـة

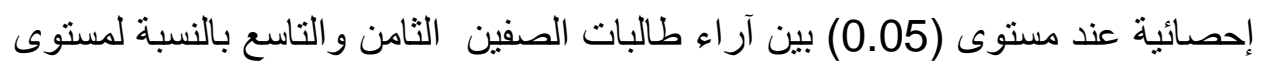




\section{تقويم أداء معلمات الرياضيات من وجهة نظر طالبات المرحلة المتوسطة بدولة الكويت}

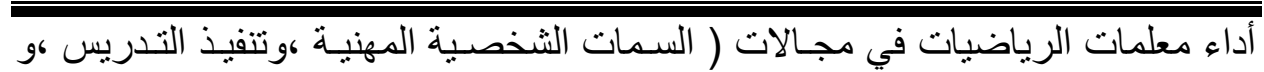
تقويم الطالبات ) ،تبعاً لمتغير الصف الدراسي . وللتحقق من صحة الفرضية ، تم استخدام اختبار "ت" T-test لحساب دلالـة الفروق بين أفر اد العينة تبعًا لمجالات (السمات الثخصية المهنية، وتنفيذ التدريس، وتقويم الطالبـات)، بالنسبة لمعلمات الرياضيات للصفوف الثامن والتاسع المتوسط ،جدول (9) يوضح ذلك.

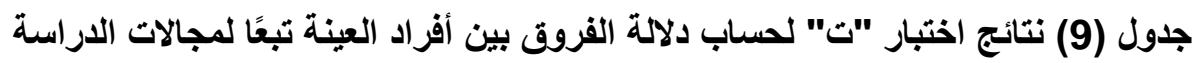

\begin{tabular}{|c|c|c|c|c|c|c|c|c|}
\hline مستوى الدلالة & 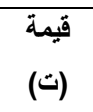 & الحرية & الالحراف & الحستبط & العدد & الصف & المجالات & p \\
\hline \multirow{2}{*}{ - } & \multirow{2}{*}{$\cdot, 9 \vee V$} & \multirow{2}{*}{ rVo } & $\cdot, 9 Y 9$ & $r, Y \vee \Lambda$ & 194 & الثامن & \multirow{2}{*}{ المهنية السمات الثخصية } & \multirow{2}{*}{1} \\
\hline & & & • & r,זTV & 110 & التاسع & & \\
\hline \multirow{2}{*}{$\cdot, 011$} & \multirow{2}{*}{$\cdot, \varepsilon \cdot \wedge$} & \multirow{2}{*}{ rvo } & $\cdot, \vee \wedge 9$ & $r, \cdot v q$ & 195 & الثامن & \multirow{2}{*}{ تنفيذ التدريس } & \multirow{2}{*}{ r } \\
\hline & & & $\cdot, \mathrm{VA}$. & $r, . \leq 4$ & 110 & التاسع & & \\
\hline \multirow{2}{*}{ - ro. } & \multirow{2}{*}{ - } & \multirow{2}{*}{ rvo } & $\cdot 949$ & $r,|r|$ & 194 & الثامن & \multirow{2}{*}{ تقويم الطالبات } & \multirow{2}{*}{$r$} \\
\hline & & & $\cdot, \wedge \varepsilon \Gamma$ & $r, r)$. & 110 & التاسع & & \\
\hline
\end{tabular}

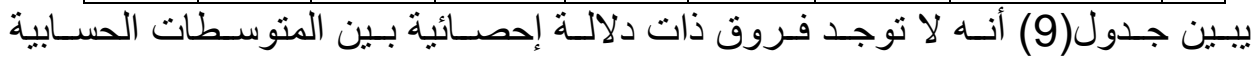

لتقدير ات طالبـات الصف الثـامن والصف التاسـع، في جميع المجـالات الثناثـة (السـمات النخصية المهنية ، وتتفيذ التدريس ، وتقويم الطالبـات)، حيث بلغت قيمـة "ت" أكثر مـن

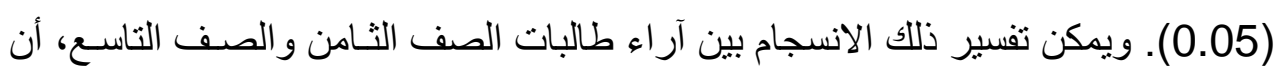

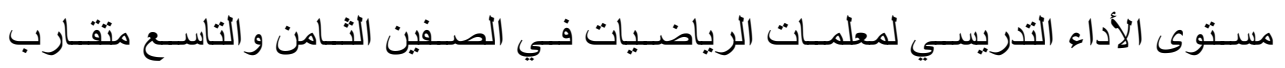
وبمستوى متوسط ،على الرغم من اختلاف المستوى العلمي لكل صـف دراسي ومتطلباتـة

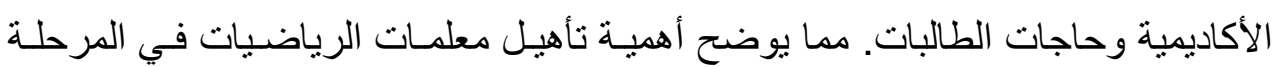

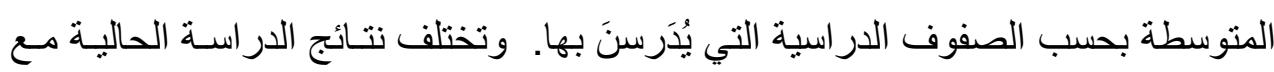

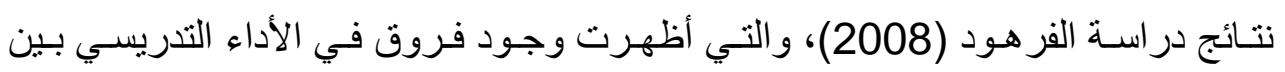
المعلمين باختلاف الصفوف الدراسية. 
في ضوء نتائج الدراسة، بوصي الباحث بالتالي:

- الاستفادة من أداة الدراسة في تقويم مستوى أداء معلمـات الرياضـيات بالمرحلـة

المتوسطة وفي جميع مر احل التعليم العام، بما يتعلق بالسمات الثخصية والأداء

$$
\text { التدريسي لمعلمات الرياضيات. }
$$

- تطوير البرامج التدريبية لمعلمات الرياضيات في المرحلة المتوسطة مـن خـلال

الاستفادة من المهار ات التدريسية والمهنية المتضمنة في أداة الدراسة.

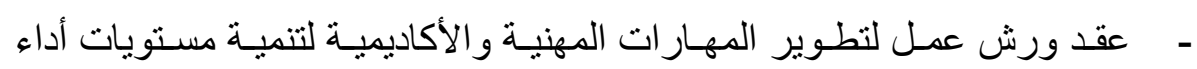

معلمات الرياضيات في مراحل التعليم العـام، وان تربط الورش في تدريس

الرياضيات بو اقع الحياة العملية لتكون مشوقة وجاذبة.

- يجـب تركيزتــدريس الرياضـيات علـى المعرفـة المفاهيميـة، وفهـم الأفكــار الرياضية، دون التركيز على المعرفة الإجرائيـة للوصـول إلـي النـاتج دون فهم

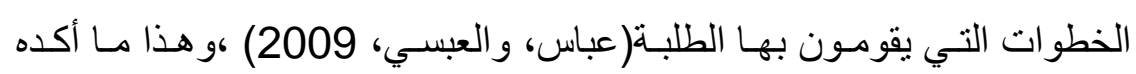
أوزابل في نظريته على أن يكون التعليم ذو معنى.

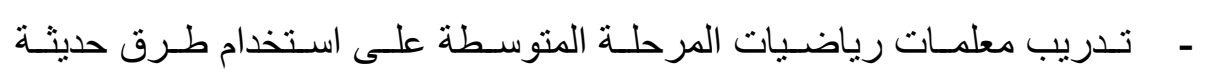
و متنو عة في طرق تدريس الرياضيات وتقويم الطالبات.

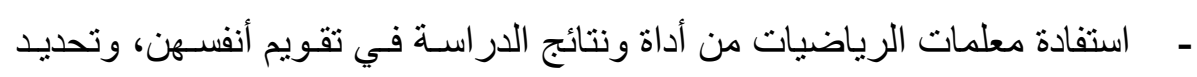

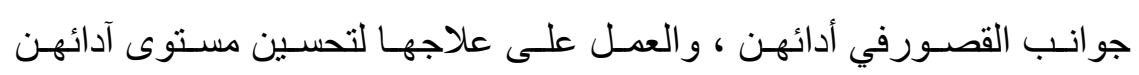

$$
\text { التدريسي والمهني. }
$$

- - تـدريب معلمـات الرياضــيات على اسـتخدام الوســائل التعليميـة والتكنولوجيـة

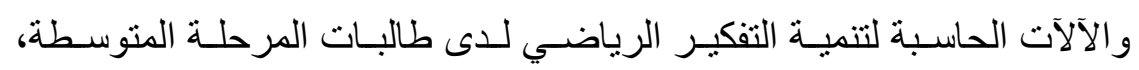
ومساعدتهم على الإبداع و الابتكار وحل المشكلات الرياضية والحياتية. 


\section{تقويم أداء معلمات الرياضيات من وجهة نظر طالبات المرحلة المتوسطة بدولة الكويت}

\section{مقترحات لاراسات مستقبلية}

- القيام بدر اسة مشابهة للار اسة الحالية على معلمي الرياضـيات ومقارنـة نتائجها

$$
\text { مع نتائج الدر اسة الحالية. }
$$

- إجر اء مزيد من الدراسات حول تقويم واقع الأداء التدريسي و المهني لمعلمي ومعلمات الرياضيات في المرحلة الابتدائية بدولة الكويت.

- إجر اء در اسات حول تقويم و اقع الأداء التدريسي و المهني لمعلمي ومعلمـات الرياضيات في المرحلة الثانوية.

- إجر اء در اسات حول تقويم معلمي ومعلمات الرياضـيات في المر احل التعليميـة باستخدام نماذج تعليمية مختلفة 
د د اسم محمد التمار

\section{المراجع العربية والأجنبية}

- ـ التوجيه الفني للرياضيات (2018) ـ التقرير السنوي ، وزارة التربية ، الكويت .

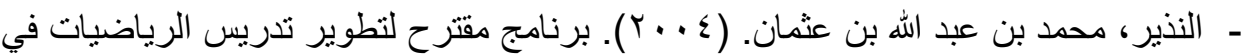
المرحلة المنوسطة. رسالة دكتور اه منشورة، جامعة الملك سعود، المملكة العربية السعودية .

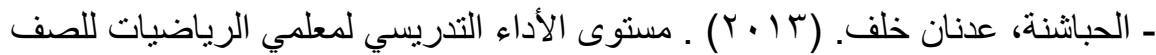
العانشر الأساسي بححافظة الكرك من وجهة نظر الطلبة. رسالة ماجستير منشورة، كلية العلوم

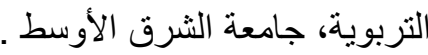

ـ الحيلة ،محمد محمود (1423) ـ مهار ات التدريس الصفي ـ دار المسيرة ، عمان ،الاردن ـ الخطيب ، محمد. (Y Y (Y). تصور مقترح للمعايير المهنية المعاصرة لمعلمي الرياضيات ومدى نو افرها لدى مجموعة من معلمي الرياضيات في السعودية. مجلة جامعة النجاح للأبحاث

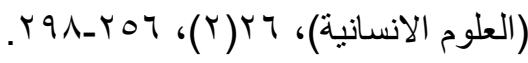
ــ الزغلول، عماد عبدالرحيم و المحاميدشـاكر عقلـة (2007) ـ سيكولوجية التدريس الصفي .دار المسيرة للنشر و التوزيع و الطباعة ، عمان ،الاردن .

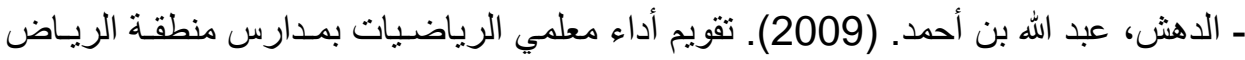
بالمملكـة العربيـة السـعودية في ضـوء المعـيير المهنيـة المعاصـرة. جامعـة المجمعـة، المملكـة

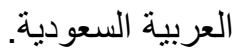
ـ العمري ، محمد بلقاسـ ( 2010) ـ الكفايـات اللازمـة لتـدريس مقرر الرياضيات المطورة ودرجة توافرها لدى المعلمين ـ رسالة ماجستير غير منشورة كليـة التربيـة، جامعـة أم القرى،

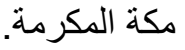
ـ العمار ،ناصر عبدالعزيز (2016) ـ تطوير التنمية المهنية للمعلمين المرحلـة المتوسطة في

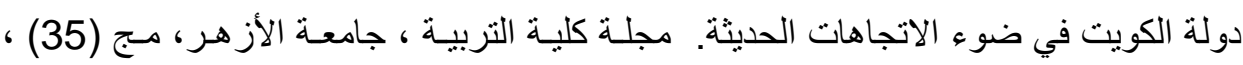
.757-795، (170)ع ــ اللقـاني، أحمــ بـن حسين؛ و الجمـل، علـي بـن أحمـــ ( 2003) ـ معجـم الــصطلحات

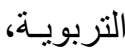
المعرفة في المناهج وطرق التدريس، القاهرة: عالم الكتب. 
تقويم أداء معلمات الرياضيات من وجهة نظر طالبات المرحلة المتوسطة بدولة الكويت

ـ المغيرة ، سلطان مبارك (2011) ـ تقويم الأداء التدريسي لمعلمي الرياضيات في المرحلـة المتوسطة بمحافظة الأحساء في ضوء معايير الجودة الثـاملة . رسـالة ماجستير غير منشـورة ،كلية العلوم الإجتماعية جامعة الأمام محمد بن سعود الإسلامية ، الرياض. ـالفرهود ،صالح (2008) ـ تدريس الرياضيات الواقع و المعوقات ـ الجمعية السـودية للعلـوم التربوية والنفسية (جسنن ) ، كلية التربية ، جامعة الملك سعود ،الرياض ، اللقاء السنوي الرابـع عشر. - جامعة الامسارات ( 2007) ـ مـؤتمر الإصـلاح المدرسـي ، التقريـر الختـامي ، دبسي ، دولـة الامار ات العربية المتحدة . - جامعة السلطان قابوس ( 2004) ـ المؤتمر الدولي بعنوان :نحو إعداد افضل لمعلم المستقبل ، مسقط سلطنة عمان ، التقرير الختامي ، - زيتون ، عايش محمود (2007) ـ النظرية البناية واسـتر اتيجيات تـدريس العلوم . عمـان دار الثروق للنشر و التوزيع . - زيتون، حسن حسـين و زيتـون ،كمـال عبدالحميـ (2003) ـ. التعلم و التـدريس مـن منظور النظرية البنائية .الطبعة الأولي ، عالم الكتب ، القاهرة . ـ سكر، نائلة نجيب و آخرون (2005) ـ تقويم اداء الطلبة المعلمين في كليـات التربيـة بجامعـة الأقصى في ضوء كفايات المعلمين اللازمة لمعلم المستقبل .المجلـة المصـرية للتربيـة العلميـة ، الجمعية المصرية للتربية العلمية ، المجلد الثامن ، العدد الر ابع ،123-157. ـ عبـاس ،محمـد خليـل ؛و العبسـي، محمـد مصـطفي (2009) . منــاهج و أسـاليب تـدريس الرياضيات للمرحلة الأساسية الدنيا ـ الطبعة الثانية ، دار المسيرة للنشـر و التوزيع و الطباعـة ، عمان.

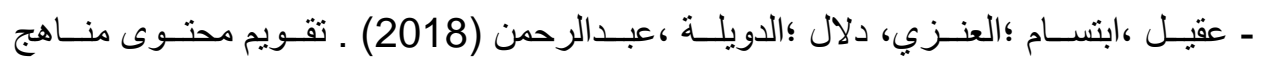
الرياضيات في المرحلة الابتدائية في دولة الكويت في ضـوء بعض معـير المجلس القومي (

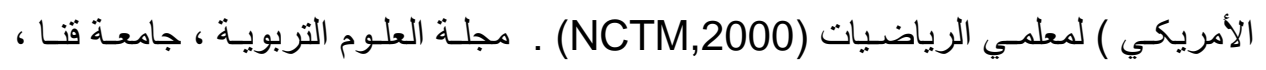
المجلد Vس، العدد ا، 17-51 
- وزارة التعليم (1437) ـ المؤتمر الخامس لإعداد المعلم المنعقد في كليـة التربيـة جامعـة أم

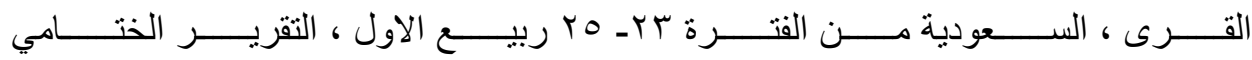
.https://forum.education-sa.com/edu17878 ، ـ وزارة التربيـة و التعليم العـالي (2014) ـ تقريـر التعليم للجميـع بحلـول عـام 2015. دولــة

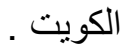

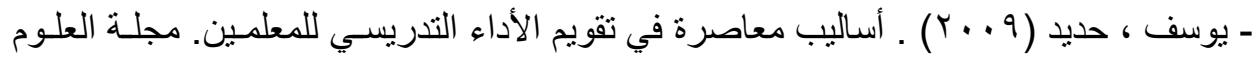

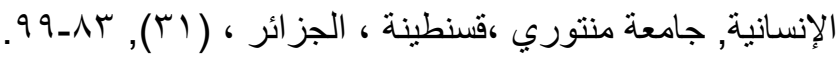

- Ac-Kgoz, Firat .(2005) . A Study on Teacher Characteristic and Their Effects on Students Attitudes, Retrieved April,17, 2007 .

- Akbas,Elif Ertem; Cancan, Murat; Kiliç, Esra .(2019) . Qualifications of an Effective Mathematics Teacher from the Perspectives of 5th to 8th Grade Secondary School Students.Universal Journal of Educational Research, v7,n 2,536-549 .

- Başar, M., Ünal, M., \& Yalçın, M. (2002). lköretim Kademesiyle Başlayan Matematik Korkusunun Nedenleri. The 5th National Science and Mathematics Education Congress, METU, Ankara, Turkey.

- Bell, Fredrick.(1987). Teaching and Learning Mathematics .University Of Pittsburgh,Wm.c.Brown company Publishers.

- Joseph,M.(2004). Implementing the National Council of Teachers of Mathematics Standards: A slow process.Review Pythagoras ,58,p46-56.

-Hardi, Tambunan et al.(2021) .Analysis Of Teacher Preference to Build Student Internet and Motivation Towards Mathematics Achievement. International Journal Of Evaluation and Research in Education, $\mathrm{v}(10), \mathrm{n}(1) 42-47$. 


\section{تقويم أداء معلمات الرياضيات من وجهة نظر طالبات المرحلة المتوسطة بدولة الكويت}

-Pozo-Munoz, C., Rebolloso-,Pacheco,E \& Fernandez-Ramirez, B. (2000). The "ideal teacher" implications for student evaluation of teacher effectiveness. Assessment \& Evaluation in Higher Education, 25(3), 253263.

-Schunk , H .( 2012) .Learning Theories: An Educational Perspective, 6th Edition University of North Carolina at Greensboro, pp 576.

-Taylor,Eric and Taylor,John .(2012) . The Effect of Evaluation on Teacher Performance . American Economic Review, 102(7): 3628-3651.

-The National Council of Teachers of Mathematics NCTM (2000). Annual Meeting; Principles and Standards for School Mathematics Chicago ‘Apr 12,

- Yesildere , I, Sibel.(2017) . The Characteristics Of a good Mathematics Teacher in Terms of Students, Mathematics, Teachers and School Administrators . Journal of a school education and technology, $\mathrm{v}(12), \mathrm{n}(3), 34-43$. 